Article

\title{
Structure, Shift in Redox Potential and Li-Ion Diffusion Behavior in Tavorite $\mathrm{LiFe}_{1-x} \mathrm{~V}_{x} \mathrm{PO}_{4} \mathrm{~F}$ Solid-Solution Cathodes
}

\author{
Jia-Li Yan, Gang-Qin Shao *(D), Shu-Hao Fan, Can Zhu, Yong Zhang, Jun Wang and Qi Liu \\ State Key Laboratory of Advanced Technology for Materials Synthesis and Processing, Wuhan University of \\ Technology, Wuhan 430070, China; 211689@whut.edu.cn (J.-L.Y.); shuhao_fan@163.com (S.-H.F.); \\ zhucan@whut.edu.cn (C.Z.); 223117@whut.edu.cn (Y.Z.); wangjun9413@whut.edu.cn (J.W.); \\ 593859987@whut.edu.cn (Q.L.) \\ * Correspondence: gqshao@whut.edu.cn; Tel./Fax: +86-27-8787-9468
}

Academic Editor: Amor M. Abdelkader

check for Received: 17 April 2019; Accepted: 13 May 2019; Published: 16 May 2019

\begin{abstract}
Solid-solution Li-ion cathode materials transform through a single-phase reaction thus leading to a long-term structural stability and improved cyclability. In this work, a two- to single-phase $\mathrm{Li}^{+}$-extraction/insertion mechanism is studied through tuning the stoichiometry of transition-metal $\mathrm{Fe} / \mathrm{V}$ cations to trigger a transition in the chemical reactivity path. Tavorite triclinic-structured $\mathrm{LiFe}_{1-x} \mathrm{~V}_{x} \mathrm{PO}_{4} \mathrm{~F}(x=0,0.1,0.3,0.5,0.7,0.9,1)$ solid-solution powders were prepared by a facile one-step solid-state method from hydrothermal-synthesized and commercial raw materials. The broad shape of cyclic voltammetry (CV) peaks, sloping charge/discharge profiles and sloping open-circuit voltage $(\mathrm{OCV})$ profiles were observed in $\mathrm{LiFe}_{1-x} \mathrm{~V}_{x} \mathrm{PO}_{4} \mathrm{~F}$ solid-solution cathodes while $0<x<1$. These confirm strongly a single-phase behavior which is different from the two-phase behavior in the end-members $(x=0$ or 1$)$. The electronegativity of $M\left(M=\mathrm{Fe}_{1-x} \mathrm{~V}_{x}\right)$ for the redox potential of $\mathrm{Fe}^{2+/ 3+}$ couple or the $M-\mathrm{O}_{4} \mathrm{~F}_{2}$ bond length for the $\mathrm{V}^{3+/ 4+}$ couple plays respectively a dominant role in $\mathrm{LiFe}_{1-x} \mathrm{~V}_{x} \mathrm{PO}_{4} \mathrm{~F}$ solid-solution cathodes.
\end{abstract}

Keywords: $\mathrm{LiFePO}_{4} \mathrm{~F}-\mathrm{LiVPO}{ }_{4} \mathrm{~F}$; solid solution; single-phase reaction; redox potential; diffusion coefficient

\section{Introduction}

Tavorite-structured $\left(P \overline{1}\right.$, triclinic) lithium transition-metal fluorophosphates $\mathrm{LiMPO}_{4} \mathrm{~F}(M=\mathrm{Fe}$, $\mathrm{V})$ with $3 \mathrm{D} \mathrm{Li}^{+}$-diffusion channels have been proposed as alternative cathode candidates for Li-ion batteries after the olivine-structured $\mathrm{LiFePO}_{4}$ (with $1 \mathrm{D}$ channels) was invented. The ionic conductivity of $\mathrm{LiFePO}_{4} \mathrm{~F}\left(0.6 \times 10^{-7} \mathrm{~S} \mathrm{~cm}^{-1}\right.$ [1] $)$ is about two orders of magnitude higher than that of $\mathrm{LiFePO}_{4}$ $\left(\sim 1 \times 10^{-9} \mathrm{~S} \mathrm{~cm}^{-1}\right.$ [2]). But the potential of $\mathrm{Fe}^{2+/ 3+}$ redox couple in the former is lower than the latter $(\sim 2.8[3,4]$ vs. $\sim 3.5 \mathrm{~V}[5])$. This can be tuned through the inductive effect introduced by the $\mathrm{V}^{3+/ 4+}$ couple $(\sim 4.28 \mathrm{~V}[6,7])$ to form $\mathrm{LiFe}_{1-x} \mathrm{~V}_{x} \mathrm{PO}_{4} \mathrm{~F}(0 \leq x \leq 1)$ solid solutions. Here we noticed that the specific capacity of $\mathrm{LiVPO}_{4} \mathrm{~F}$ is almost the same as that of $\mathrm{LiFePO}_{4} \mathrm{~F}\left(151.6\right.$ vs. $155.9 \mathrm{mAh} \mathrm{g}^{-1}$ ), and the specific energy of $\mathrm{LiVPO}_{4} \mathrm{~F}$ [8-20] is larger than that of $\mathrm{LiFePO}_{4} \mathrm{~F}[4,21-23]\left(667 \mathrm{vs}\right.$. $\left.424 \mathrm{Wh} \mathrm{kg}^{-1}\right)$.

Solid-solution $\mathrm{Li}$-ion cathode materials transform through a single-phase reaction, leading to a long-term structural stability and improved cyclability, while their end-members transform through a two-phase reaction [24-26]. $\mathrm{LiFePO}_{4} \mathrm{~F}, \mathrm{LiVPO}_{4} \mathrm{~F}$ and $\mathrm{LiVPO}_{4} \mathrm{O}$ have homotypic structures. We have reported recently the $\mathrm{LiFePO}_{4} \mathrm{~F}-\mathrm{LiVPO}_{4} \mathrm{O}$ solid solutions (i.e., $\mathrm{LiFe}_{1-x} \mathrm{~V}_{x} \mathrm{PO}_{4} \mathrm{~F}_{1-\delta} \mathrm{O}_{\delta}(0 \leq x \leq 1$; $0 \leq \delta \leq 0.36)$ ) [26]. Otherwise, there are some publications related to $\mathrm{LiVPO}_{4} \mathrm{~F}-\mathrm{LiVPO}_{4} \mathrm{O}$ [27-31] and a few to $\mathrm{LiFePO}_{4} \mathrm{~F}-\mathrm{LiVPO}_{4} \mathrm{~F}[25,32]$ solid solutions. Not much information can be collected from the meeting abstract [32]. Huang et al. [25] synthesized $\mathrm{LiFe}_{0.5} \mathrm{~V}_{0.5} \mathrm{PO}_{4} \mathrm{~F}$ solid-solution which showed a 
single-phase behavior over the lithium composition range of $\mathrm{Li}_{1-y} \mathrm{Fe}_{0.5} \mathrm{~V}_{0.5} \mathrm{PO}_{4} \mathrm{~F}(0<y<0.5)$ with two alternating electrochemical active regions centered at $\sim 2.76$ and $\sim 4.3 \mathrm{~V}$.

In this work, $\mathrm{LiFe}_{1-x} \mathrm{~V}_{x} \mathrm{PO}_{4} \mathrm{~F}(x=0,0.1,0.3,0.5,0.7,0.9,1)$ powders, cathodes and the corresponding Li-ion batteries were prepared and characterized. The object is to study the two- to single-phase $\mathrm{Li}^{+}$-extraction/insertion mechanism through tuning the transition-metal stoichiometry of cations to trigger a transition in the chemical reactivity path.

\section{Results}

\subsection{Phase Structure}

Figure 1 shows $\mathrm{XRD}$ full patterns of $\mathrm{LiFe}_{1-x} \mathrm{~V}_{x} \mathrm{PO}_{4} \mathrm{~F}(0 \leq x \leq 1)$ powders. Tables S1-S7 list Rietveld refined parameters of the corresponding tavorite structures. Table S8 shows comparison of lattice parameters for $\mathrm{LiFe}_{1-x} \mathrm{~V}_{x} \mathrm{PO}_{4} \mathrm{~F}(0 \leq x \leq 1)$ samples and the related publications. Figure $\mathrm{S} 1$ shows the final observed, calculated and difference profiles of the tavorite-structured $\mathrm{LiFePO}_{4} \mathrm{~F}$, $\mathrm{LiFe}_{0.9} \mathrm{~V}_{0.1} \mathrm{PO}_{4} \mathrm{~F}, \mathrm{LiFe}_{0.7} \mathrm{~V}_{0.3} \mathrm{PO}_{4} \mathrm{~F}, \mathrm{LiFe}_{0.5} \mathrm{~V}_{0.5} \mathrm{PO}_{4} \mathrm{~F}, \mathrm{LiFe}_{0.3} \mathrm{~V}_{0.7} \mathrm{PO}_{4} \mathrm{~F}, \mathrm{LiFe}_{0.1} \mathrm{~V}_{0.9} \mathrm{PO}_{4} \mathrm{~F}$ and $\mathrm{LiVPO}_{4} \mathrm{~F}$ via Rietveld refinements. Figure S2 shows variations of lattice parameters and unit cell volumes of $\mathrm{LiFe}_{1-x} \mathrm{~V}_{x} \mathrm{PO}_{4} \mathrm{~F}(0 \leq x \leq 1)$ solid solutions. Further details of crystal structures may be obtained from the website listed in Appendix A. Under harsh testing conditions, pure $\mathrm{LiVPO}_{4} \mathrm{~F}$ and $\mathrm{LiFe}_{0.3} \mathrm{~V}_{0.7} \mathrm{PO}_{4} \mathrm{~F}$ phases have been attained. There are a few $\mathrm{LiFePO}_{4}$ impurities $(\sim 1.7, \sim 2.4, \sim 4.1$ and $6.3 \% \mathrm{wt}$, respectively) when $x=0,0.1,0.3$ and 0.5 , and $\mathrm{VPO}_{4}$ impurity $(\sim 7.5 \% \mathrm{wt})$ when $x=0.9$ in $\mathrm{LiFe}_{1-x} \mathrm{~V}_{x} \mathrm{PO}_{4} \mathrm{~F}$ $(0 \leq x \leq 1)$ samples, which will be further discussed in electrochemical measurements (Section 2.4).

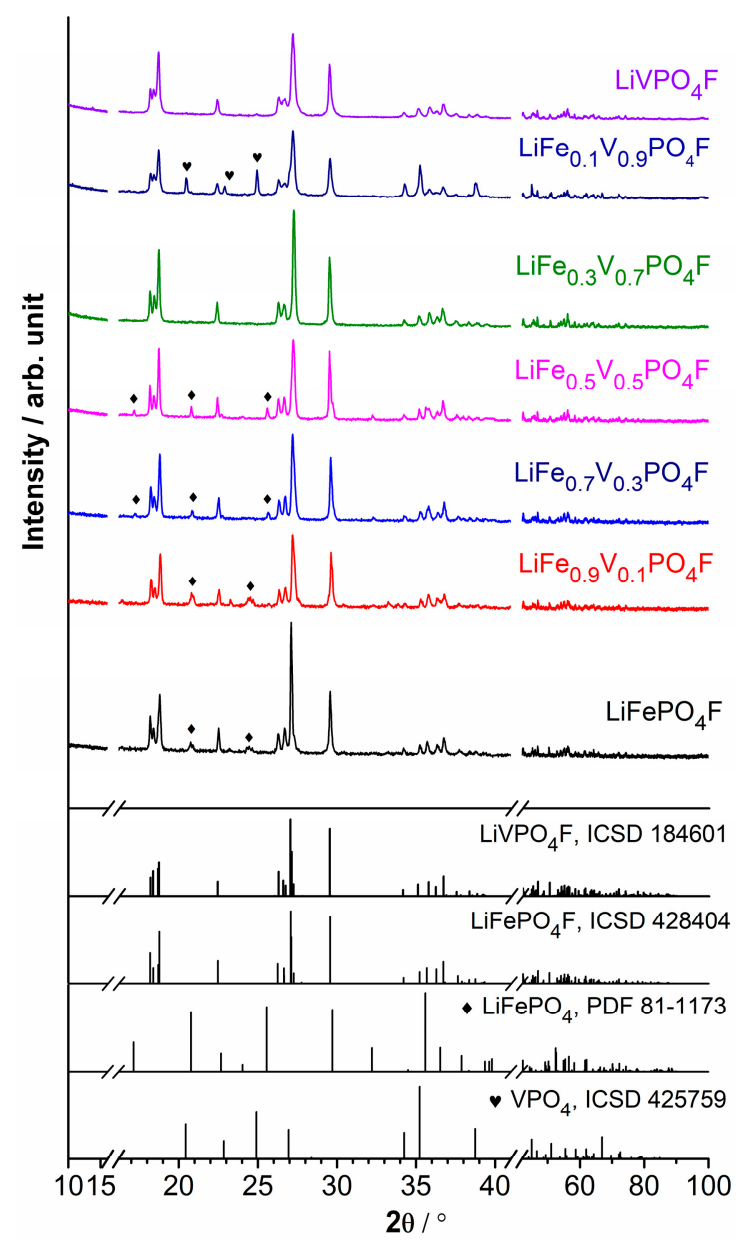

Figure 1. $\mathrm{XRD}$ full patterns of $\mathrm{LiFe}_{1-x} \mathrm{~V}_{x} \mathrm{PO}_{4} \mathrm{~F}(0 \leq x \leq 1)$ powders. 
Considering the crystal structures are triclinic, the continuous substitutions lead to a versatile change of interplanar crystal spacing. Refinements reveal that solid-solution domains exist without phase separation [25,32]. Lattice parameters $(\boldsymbol{a}, \boldsymbol{b}, \boldsymbol{c}, \alpha, \beta, \gamma)$ and unit cell volumes $(V)$ of end-members $(x=0$ and 1$)$ agree well with our previous results $[4,26,33]$. There is only one crystallographic Li site $(2 i)[7,11]$ and two independent $\mathrm{Fe} / \mathrm{V}$ sites $(1 a$ and $1 c)$ in the unit cell. The $M-\mathrm{O}_{4} \mathrm{~F}_{2}$ chains $\left(M=\mathrm{Fe}_{1-x} \mathrm{~V}_{x}\right)$ along the $b$ axis constitute an alternation of $M 1$ and $M 2$ centered octahedra which are slightly distorted. The F ligands (2i) act as the bridging ligands. Each oxygen ( $2 i)$ from the equatorial plane of the octahedron is common to a $\mathrm{PO}_{4}$ tetrahedron bridging the $M-\mathrm{O}_{4} \mathrm{~F}_{2}$ chains, leading to the formation of a 3D framework. The systematic variations in lattice parameters and unit cell volumes of $\mathrm{LiFe}_{1-x} \mathrm{~V}_{x} \mathrm{PO}_{4} \mathrm{~F}(0<x<1)$ samples confirm the formation of homogeneous solid solutions, which originate from substitutions by the $\mathrm{V}^{3+}\left(r_{\mathrm{V}^{3+}}=0.640 \AA\right)$ for $\mathrm{Fe}^{3+}\left(r_{\mathrm{Fe}^{3+}}{ }_{\mathrm{HS}}=0.645 \AA\right.$ in a high spin (HS) state) with close effective ionic radii while the coordination number $(\mathrm{CN})$ is $6[3,34,35]$. The published unit cell volumes $V\left(\AA^{3}\right)$ of the related phases are collected as follows: $\mathrm{LiFePO}_{4} \mathrm{~F}(173.91(2)$ [22], 173.67(6) [23], 173.558(6) [4]), $\mathrm{LiVPO}_{4} \mathrm{~F}$ (174.36(2) [11], 174.31 [36], 174.25(1) [30], 174.167(16) [33]) and $\mathrm{LiVPO}_{4} \mathrm{O}(171.018(1)$ [11], 171.227(2) [37], 171.578(3) [38]). Therefore, the volume deviation $(\Delta V)$ between $\mathrm{LiFePO}_{4} \mathrm{~F}$ and $\mathrm{LiVPO}_{4} \mathrm{~F}$ is under $0.47 \%$, much less than that between $\mathrm{LiFePO}_{4} \mathrm{~F}$ and $\mathrm{LiVPO}_{4} \mathrm{O}$ (under 1.7\%). For example, the $V$ value $\left(173.25(1) \AA^{3}\right.$ ) of $\mathrm{LiFe}_{0.5} \mathrm{~V}_{0.5} \mathrm{PO}_{4} \mathrm{~F}$ (the only $\mathrm{LiFePO}_{4} \mathrm{~F}-\mathrm{LiVPO}_{4} \mathrm{~F}$ solid-solution reported) is not located between end-members thus against the Vegard's law [25]. It may be caused by experiment errors because of the small volume deviation. However, the $V$ values of $\mathrm{LiFePO}_{4} \mathrm{~F}-\mathrm{LiVPO}_{4} \mathrm{O}$ solid solutions are located between end-members [26]. In this work, the $V$ values of the prepared $\mathrm{LiFePO}_{4} \mathrm{~F}-\mathrm{LiVPO}_{4} \mathrm{~F}$ samples are located in a narrow region $(0.33-0.85 \%$; Figure S2) due to the close effective ionic radii of $\mathrm{Fe}^{3+}(0.645 \AA)$ and $\mathrm{V}^{3+}(0.640 \AA)$, indicating the formation of solid solutions.

\subsection{Powder Microstructure}

Figure 2 shows SEM images of $\mathrm{FePO}_{4}, \mathrm{VPO}_{4}, \mathrm{LiFe}_{0.5} \mathrm{~V}_{0.5} \mathrm{PO}_{4} \mathrm{~F}$ and $\mathrm{LiVPO}_{4} \mathrm{~F}$, and the energy dispersive spectra (EDS) mapping of $\mathrm{LiFe}_{0.5} \mathrm{~V}_{0.5} \mathrm{PO}_{4} \mathrm{~F}$.
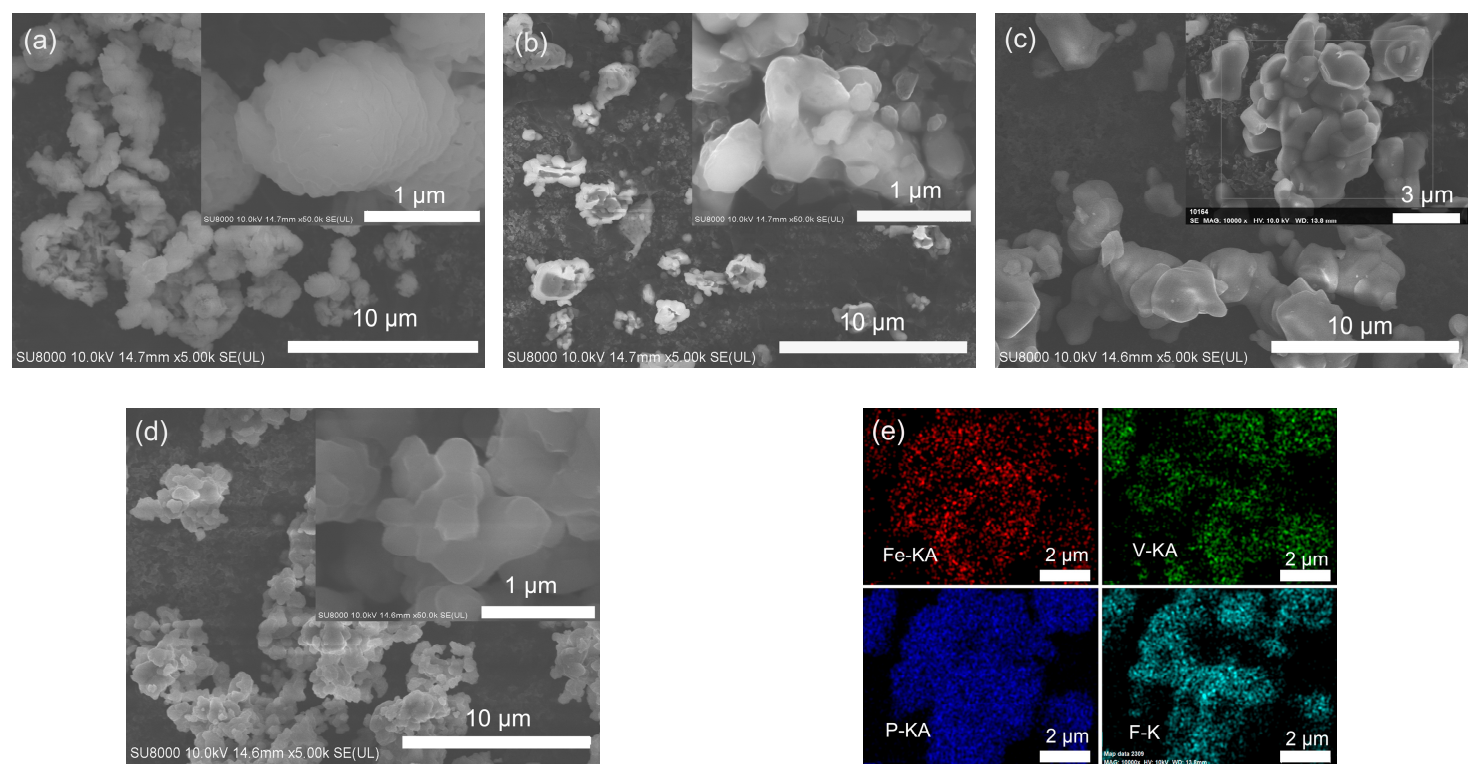

Figure 2. SEM images of $\mathrm{FePO}_{4}(\mathbf{a}), \mathrm{VPO}_{4}(\mathbf{b}), \mathrm{LiFe}_{0.5} \mathrm{~V}_{0.5} \mathrm{PO}_{4} \mathrm{~F}(\mathbf{c})$ and $\mathrm{LiVPO}_{4} \mathrm{~F}(\mathbf{d})$, and the EDS mapping of $\mathrm{LiFe}_{0.5} \mathrm{~V}_{0.5} \mathrm{PO}_{4} \mathrm{~F}$ (e) from the inset in Figure 2c.

The particle size is 1-2 $\mu \mathrm{m}$ for $\mathrm{FePO}_{4}$ (Figure 2a), 0.5-1 $\mu \mathrm{m}$ for $\mathrm{VPO}_{4}$ (Figure 2b), 1-2 $\mu \mathrm{m}$ for $\mathrm{LiFe}_{0.5} \mathrm{~V}_{0.5} \mathrm{PO}_{4} \mathrm{~F}$ (Figure $2 \mathrm{c}$ ) and $0.5-1.5 \mu \mathrm{m}$ for $\mathrm{LiVPO}_{4} \mathrm{~F}$ (Figure $2 \mathrm{~d}$ ). The EDS test confirms a nearly-nominal proportion (Fe: $\mathrm{V}: \mathrm{P}=0.46: 0.57: 1, \% \mathrm{~mol}$ ) and a homogeneous distribution of Fe, $\mathrm{V}, \mathrm{P}$ 
and $\mathrm{F}$ components in the $\mathrm{LiFe}_{0.5} \mathrm{~V}_{0.5} \mathrm{PO}_{4} \mathrm{~F}$ solid solutions (Figure 2e), indicating that substitutions are successful.

\subsection{Valence States of Fe/V Components}

The core level X-ray photoelectron spectra (XPS) of $\mathrm{FePO}_{4}, \mathrm{VPO}_{4}$ and $\mathrm{LiFe}_{1-x} \mathrm{~V}_{x} \mathrm{PO}_{4} \mathrm{~F}$ $(0 \leq x \leq 1)$ powders are shown in Figure $3 \mathrm{a}$. The Fe $2 \mathrm{p}$ (or V $2 \mathrm{p}$ ) spectrum consists of two components (Fe $2 p_{3 / 2} / F e 2 p_{1 / 2}$ or V $2 p_{3 / 2} / V 2 p_{1 / 2}$ ) due to spin-orbit (j-j) coupling/splitting (Figure 3b,c) $[39,40]$.
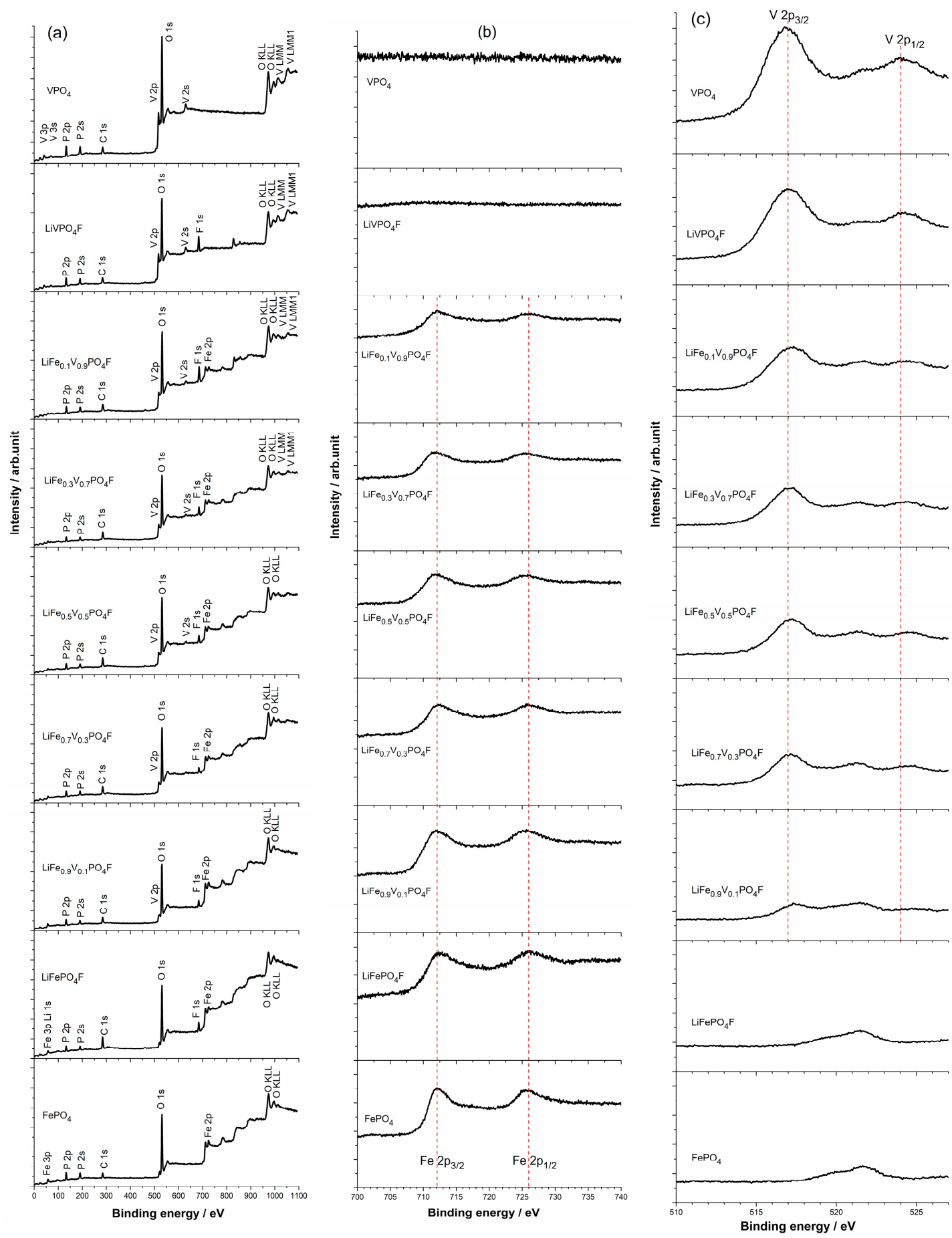

Figure 3. X-ray photoelectron spectra (XPS) of $\mathrm{FePO}_{4}, \mathrm{VPO}_{4}$ and $\mathrm{LiFe}_{1-x} \mathrm{~V}_{x} \mathrm{PO}_{4} \mathrm{~F}(0 \leq x \leq 1)$ powders (a). Binding energy regions of the Fe $2 p(b)$ and $V 2 p(c)$ show spin-orbit splitting of $2 \mathrm{p}_{3 / 2}$ and $2 \mathrm{p}_{1 / 2}$, respectively. 
In Figure $3 b$, main peaks of $\mathrm{Fe} 2 \mathrm{p}_{3 / 2}$ and $\mathrm{Fe} 2 \mathrm{p}_{1 / 2}$ centered respectively at $\sim 712 / 726 \mathrm{eV}$ are assigned to the high-spin $\mathrm{Fe}^{3+}$ species with the $(3 \mathrm{~d} \uparrow)^{5}(3 \mathrm{~d} \downarrow)^{0}$ electronic configuration [41], similar to the reported $\mathrm{FePO}_{4}(712.5 / 726 \mathrm{eV}[39,42])$. The Fe $2 \mathrm{p}_{3 / 2}$ peak is narrower and stronger than Fe $2 \mathrm{p}_{1 / 2}$, and the area of Fe $2 p_{3 / 2}$ is greater than that of Fe $2 p_{1 / 2}$ because $2 p_{3 / 2}$ has the degeneracy of four multiplets while $2 \mathrm{p}_{1 / 2}$ has only two in $j-j$ coupling $[40,41]$. By contrast, for a high-spin $\mathrm{Fe}^{2+}$ species like $\mathrm{LiFePO}_{4}$ with $(3 d \uparrow)^{5}(3 d \downarrow)^{1}$ configuration, main peaks of $F e 2 p_{3 / 2}$ and Fe $2 p_{1 / 2}$ are centered at $710.5 / 724 \mathrm{eV}$, respectively $[39,42]$.

In Figure $3 c$, main peaks of $V 2 p_{3 / 2}$ and $V 2 p_{1 / 2}$ centered respectively at $\sim 517 / 524$ eV are assigned to the $\mathrm{V}^{3+}$ species with the $(3 \mathrm{~d} \uparrow)^{2}(3 \mathrm{~d} \downarrow)^{0}$ electronic configuration [43], similar to the reported $\mathrm{VPO}_{4}$ (517.3/524.8 eV [44]) and $\mathrm{LiVPO}_{4} \mathrm{~F}$ (517.3/524.7 eV [44]; 517.2/523.0 eV [45]; 517.1/523.4 eV [46]; $517.38 / 524.81 \mathrm{eV}[31])$. By contrast, for a $\mathrm{V}^{4+}$ species like $\mathrm{LiVPO}_{4} \mathrm{O}$ with $(3 \mathrm{~d} \uparrow)^{1}(3 \mathrm{~d} \downarrow)^{0}$ configuration, main peaks of $\mathrm{V} 2 \mathrm{p}_{3 / 2}$ and $\mathrm{V} 2 \mathrm{p}_{1 / 2}$ are centered at $518.09 / 525.38 \mathrm{eV}$, respectively [31]. It can be concluded then that valence states of $\mathrm{Fe}$ and $\mathrm{V}$ are +3 in $\mathrm{FePO}_{4}, \mathrm{VPO}_{4}$ and $\mathrm{LiFe}_{1-x} \mathrm{~V}_{x} \mathrm{PO}_{4} \mathrm{~F}(0 \leq x \leq 1)$ samples.

\subsection{Shift in Redox Potential}

Figure 4 shows cyclic voltammetry $(\mathrm{CV})$ curves of $\mathrm{LiFe}_{1-x} \mathrm{~V}_{x} \mathrm{PO}_{4} \mathrm{~F}(x=0,0.1,0.3,0.5,0.7,0.9,1)$ cells with the same sweep rate of $0.1 \mathrm{mV} \mathrm{s}^{-1}$ for five cycles. Figure 5 shows $\mathrm{CV}$ curves of $\mathrm{LiFe}_{0.5} \mathrm{~V}_{0.5} \mathrm{PO}_{4} \mathrm{~F}$ and $\mathrm{LiFe}_{0.3} \mathrm{~V}_{0.7} \mathrm{PO}_{4} \mathrm{~F}$ cells with different sweep rates of $0.1 / 0.2 / 0.3 / 0.4 / 0.5 \mathrm{mV} \mathrm{s}^{-1}$ for 15 cycles. Figure 6 shows total reactions in $\mathrm{LiFe}_{1-x} \mathrm{~V}_{x} \mathrm{PO}_{4} \mathrm{~F}(0 \leq x \leq 1)$ cells. The $\mathrm{CV}$ data of $\mathrm{LiFePO}_{4} \mathrm{~F}$ are consistent with our previous results [4,26] and that of others [1], in which a pair (cathodic/anodic) of redox peaks exist at 2.659/2.910 V assigned to the $\mathrm{Fe}^{2+/ 3+}$ couple for $\mathrm{Li}_{2} \mathrm{Fe}^{\mathrm{II}} \mathrm{PO}_{4} \mathrm{~F} / \mathrm{LiFe}^{\mathrm{III}} \mathrm{PO}_{4} \mathrm{~F}$. The CV data of $\mathrm{LiVPO}_{4} \mathrm{~F}$ are in good agreement with results of the reported differential capacity vs. voltage curves $[6,47,48]$ and CV tests $[44,49]$. Split anodic peaks at 4.270/4.339 V ascribes to the occurrence of an intermediate phase $\left(\mathrm{Li}_{0.67} \mathrm{VPO}_{4} \mathrm{~F}\right.$, i.e., $\left.\mathrm{Li}_{0.67} \mathrm{~V}_{0.67}^{\mathrm{III}} \mathrm{V}_{0.33}^{\mathrm{IV}} \mathrm{PO}_{4} \mathrm{~F}\right)$ during oxidation $\left(\mathrm{Li}^{+}\right.$-extraction),

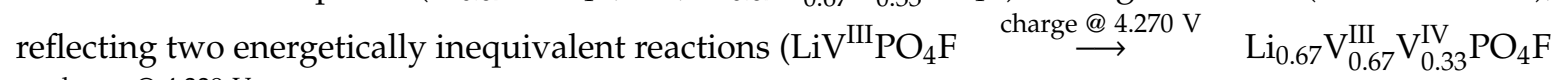
charge @ $4.339 \mathrm{~V}$

$\left.\mathrm{V}^{\mathrm{IV}} \mathrm{PO}_{4} \mathrm{~F}\right)$. The corresponding structure evolution is: triclinic $P \overline{1} \rightarrow$ triclinic $P \overline{1} \rightarrow$ monoclinic $C 2 / c[7,11]$. A single cathodic peak at $4.133 \mathrm{~V}$ characterizes a two-phase $\mathrm{Li}^{+}$-insertion process $\left(\mathrm{V}^{\mathrm{IV}} \mathrm{PO}_{4} \mathrm{~F} \quad \stackrel{\text { discharge @ }}{\longrightarrow} .133 \mathrm{~V} \quad \mathrm{LiV}^{\mathrm{III}} \mathrm{PO}_{4} \mathrm{~F}\right)$. The corresponding structure evolution is: monoclinic $\mathrm{C} 2 / \mathrm{c} \rightarrow$ triclinic $P \overline{1}[6,44,47-49]$.

For $\mathrm{LiFe}_{1-x} \mathrm{~V}_{x} \mathrm{PO}_{4} \mathrm{~F}$ samples $(0<x<1)$, there still exists a pair of redox peaks assigned to the $\mathrm{Fe}^{2+/ 3+}$ couple in which systematic shifts of cathodic/anodic peaks were observed. This will be discussed in detail later. There also exists two anodic peaks (or overlapping peaks while $x=0.3$, 0.5 and 0.7 ) at $4.266-4.361 \mathrm{~V}$ similar to $\mathrm{LiVPO}_{4} \mathrm{~F}$, indicating the occurrence of intermediate phases $\left(\mathrm{Li}_{1-0.33 x} \mathrm{Fe}_{1-x}^{\mathrm{III}} \mathrm{V}_{0.67 x}^{\mathrm{III}} \mathrm{V}_{0.33 x}^{\mathrm{IV}} \mathrm{PO}_{4} \mathrm{~F}\right.$, triclinic, $\left.P \overline{1}\right)[7,11]$. There is a single cathodic peak at $4.126 \pm 0.027 \mathrm{~V}$ which characterizes a two-phase $\mathrm{Li}^{+}$-insertion process $\left(\mathrm{Li}_{1-x} \mathrm{Fe}_{1-x}^{\mathrm{III}} \mathrm{V}_{x}^{\mathrm{IV}} \mathrm{PO}_{4} \mathrm{~F} \quad \stackrel{\text { discharge } @ ~}{4.126 \pm 0.027 \mathrm{~V}}\right.$ $\left.\mathrm{LiFe}_{1-x}^{\mathrm{III}} \mathrm{V}_{x}^{\mathrm{III}} \mathrm{PO}_{4} \mathrm{~F}\right)$. The corresponding structure evolution is: monoclinic $C 2 / c \rightarrow$ triclinic $P \overline{1}$. Important to note is the shape of $\mathrm{CV}$ peaks. The broad shape of $\mathrm{CV}$ peaks for $\mathrm{LiFe}_{1-x} \mathrm{~V}_{x} \mathrm{PO}_{4} \mathrm{~F}$ solid-solution samples while $0<x<1$, instead of the sharp and narrow peaks as observed in end-members $(x=0$ or $1)$, is indicative of a single-phase solid-solution behavior [7,25]. Otherwise, the pair of redox peaks at $\sim 3.35 / 3.55 \mathrm{~V}$ when $x=0.1,0.3$ and 0.5 are assigned to the $\mathrm{Fe}^{2+/ 3+}$ couple for $\mathrm{LiFePO}_{4}$ impurity (Figure $4 b, c)$, consistent with the XRD results (Figure 1). Note that the current $\left(\mathrm{A} \mathrm{g}^{-1}\right)$ for Fe $^{2+/ 3+}$ couple in $\mathrm{LiFePO}_{4}$ impurity is one order of magnitude smaller than that for $\mathrm{Fe}^{2+/ 3+}$ couple in $\mathrm{LiFe}_{0.9} \mathrm{~V}_{0.1} \mathrm{PO}_{4} \mathrm{~F}$ sample, indicating that the impurity content is very small while the V-doping amount is low (Figure $4 \mathrm{c}$ ). The above electrochemical reactions can be summarized as the following:

$$
\begin{aligned}
& \mathrm{LiFeV}_{1-x}^{\mathrm{III}} \mathrm{V}_{x}^{\mathrm{III}} \mathrm{PO}_{4} \mathrm{~F} \quad \stackrel{\text { charge @ } ~}{\longrightarrow} 4.3 \mathrm{~V} \quad \mathrm{Li}_{1-0.33 x} \mathrm{Fe}_{1-x}^{\mathrm{III}} \mathrm{V}_{0.67 \mathrm{x}}^{\mathrm{III}} \mathrm{V}_{0.33 x}^{\mathrm{IV}} \mathrm{PO}_{4} \mathrm{~F}+0.33 x \mathrm{Li}^{+}+0.33 x \mathrm{e}^{-} \text {, } \\
& \mathrm{Li}_{1-0.33 x} \mathrm{Fe}_{1-x}^{\mathrm{III}} \mathrm{V}_{0.67 x}^{\mathrm{III}} \mathrm{V}_{0.33 x}^{\mathrm{IV}} \mathrm{PO}_{4} \mathrm{~F} \quad \stackrel{\text { charge @ } ~}{\longrightarrow} .4 \mathrm{~V} \quad \mathrm{Li}_{1-x} \mathrm{Fe}_{1-x}^{\mathrm{III}} \mathrm{V}_{x}^{\mathrm{IV}} \mathrm{PO}_{4} \mathrm{~F}+0.67 x \mathrm{Li}^{+}+0.67 x \mathrm{e}^{-} \text {, }
\end{aligned}
$$




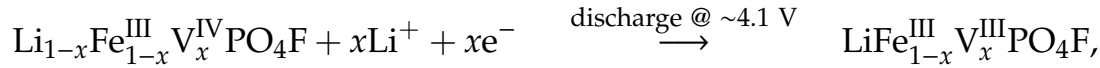

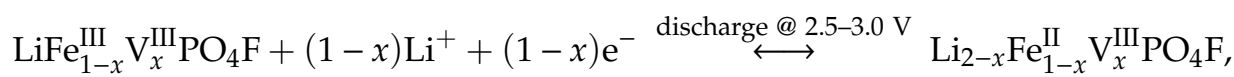

Therefore, whether $\mathrm{LiFe}_{1-x} \mathrm{~V}_{x} \mathrm{PO}_{4} \mathrm{~F}$ cells $(0 \leq x \leq 1)$ cycled in the range of $2.0-4.5 \mathrm{~V}$ charge firstly and discharge subsequently, or vice versa, total reactions can be concluded shown in Figure 6 . Now the end-member phases change from $\mathrm{LiFePO}_{4} \mathrm{~F} / \mathrm{LiVPO}_{4} \mathrm{~F}$ to $\mathrm{Li}_{2-x} \mathrm{Fe}_{1-x}^{\mathrm{II}} \mathrm{V}_{x}^{\mathrm{III}} \mathrm{PO}_{4} \mathrm{~F} / \mathrm{Li}_{1-x} \mathrm{Fe}_{1-x}^{\mathrm{III}} \mathrm{V}_{x}^{\mathrm{IV}} \mathrm{PO}_{4} \mathrm{~F}$.

When $\mathrm{LiFe}_{1-x} \mathrm{~V}_{x} \mathrm{PO}_{4} \mathrm{~F}(x=0,0.1,0.3,0.5,0.7,0.9,1)$ cells cycle at $0.1 \mathrm{mV} \mathrm{s}^{-1}$ (Figure 4 ), or cycle respectively at $0.2,0.3,0.4$ and $0.5 \mathrm{mV} \mathrm{s}^{-1}$, the cathodic/anodic peaks remain unmoved and peak areas increase, indicating that they have good structural stability and good cyclability (Figure 5). But cathodic/anodic peaks shift during sweep rates changing. When cells cycle from a lower rate to a higher one $\left(0.1 \rightarrow 0.2 \rightarrow 0.3 \rightarrow 0.4 \rightarrow 0.5 \mathrm{mV} \mathrm{s}^{-1}\right)$, cathodic peaks shift to lower potentials and the corresponding anodic peaks shift to higher potentials. Simultaneously, the potential differences $\left(\Delta E_{p}\right)$ increase from $0.36 \mathrm{~V}$ to $0.47 \mathrm{~V}$ for $\mathrm{Fe}^{2+/ 3+}$ couple and from $0.23 \mathrm{~V}$ to $0.44 \mathrm{~V}$ for $\mathrm{V}^{3+/ 4+}$ couple in the $\mathrm{LiFe}_{0.5} \mathrm{~V}_{0.5} \mathrm{PO}_{4} \mathrm{~F}$ cell. Additionally, $\Delta E_{p}$ increases from $0.35 \mathrm{~V}$ to $0.53 \mathrm{~V}$ for $\mathrm{Fe}^{2+/ 3+}$ couple and from $0.25 \mathrm{~V}$ to $0.32 \mathrm{~V}$ for $\mathrm{V}^{3+/ 4+}$ couple in the $\mathrm{LiFe}_{0.3} \mathrm{~V}_{0.7} \mathrm{PO}_{4} \mathrm{~F}$ cell. This is due to electrode kinetics or electrode polarization related to the formation of SEI (solid electrolyte interface) film, side reactions, capacity-fading, etc. Slight differences in shapes of anodic/cathodic peaks are due to cycle reforming $[1,4,26,50]$.
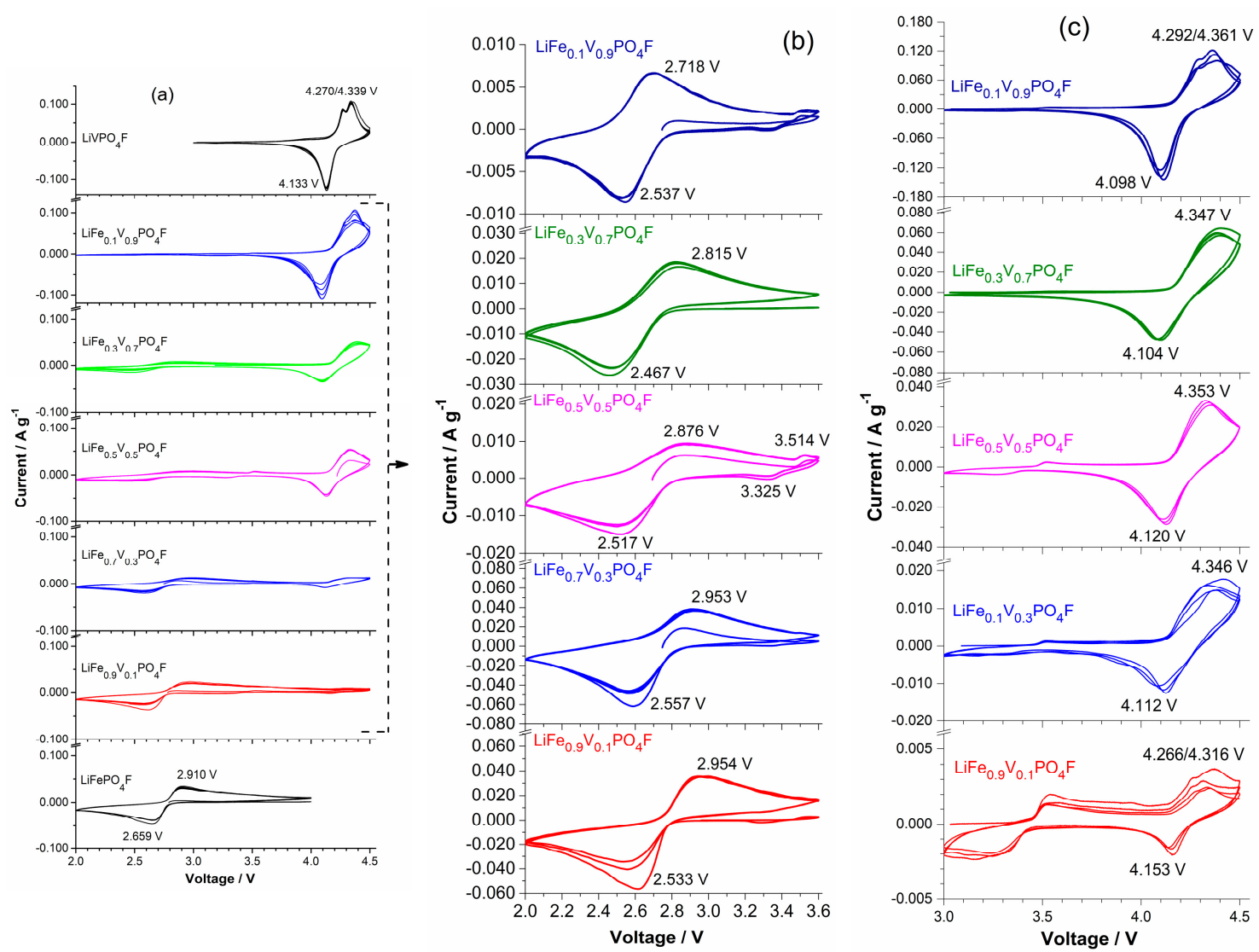

Figure 4. Cyclic voltammetry (CV) curves of $\mathrm{LiFe}_{1-x} \mathrm{~V}_{x} \mathrm{PO}_{4} \mathrm{~F}(x=0,0.1,0.3,0.5,0.7,0.9,1)$ cells with the same sweep rate of $0.1 \mathrm{mV} \mathrm{s}^{-1}$ for five cycles in the range of $2.0-4.5 \mathrm{~V} \mathrm{(a)}, 2.0-3.6 \mathrm{~V}(\mathbf{b})$ and 3.0-4.5 V (c). With the exception of the starting half cycle, all of peak positions are from the second cycle. 

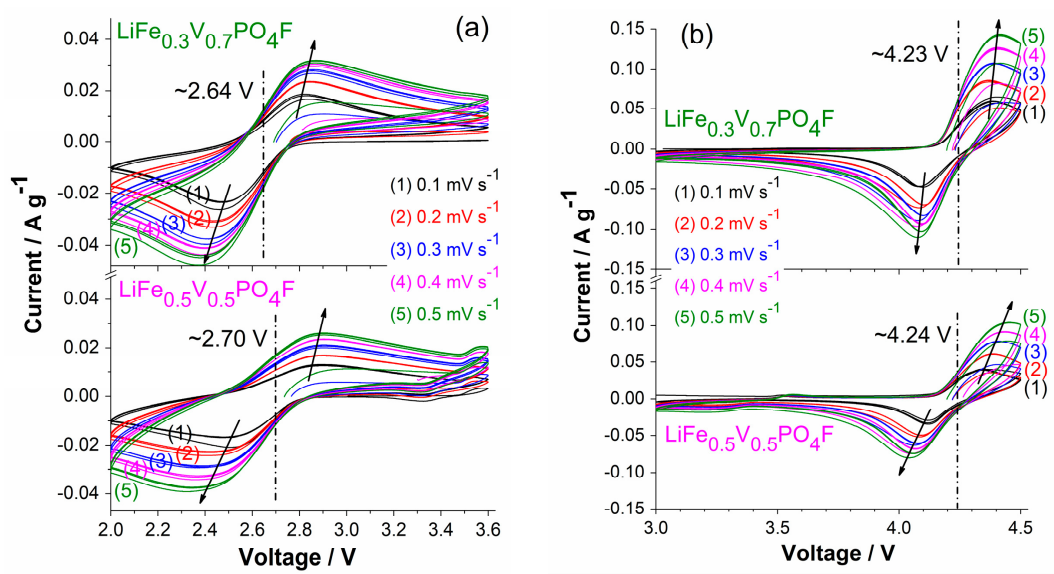

Figure 5. $\mathrm{CV}$ curves of $\mathrm{LiFe}_{0.5} \mathrm{~V}_{0.5} \mathrm{PO}_{4} \mathrm{~F}$ and $\mathrm{LiFe}_{0.3} \mathrm{~V}_{0.7} \mathrm{PO}_{4} \mathrm{~F}$ cells with different sweep rates of $0.1 / 0.2 / 0.3 / 0.4 / 0.5 \mathrm{mV} \mathrm{s}^{-1}$ for 15 cycles in the range of 2.0-3.6 $\mathrm{V}$ (a) and 3.0-4.5 $\mathrm{V}$ (b).

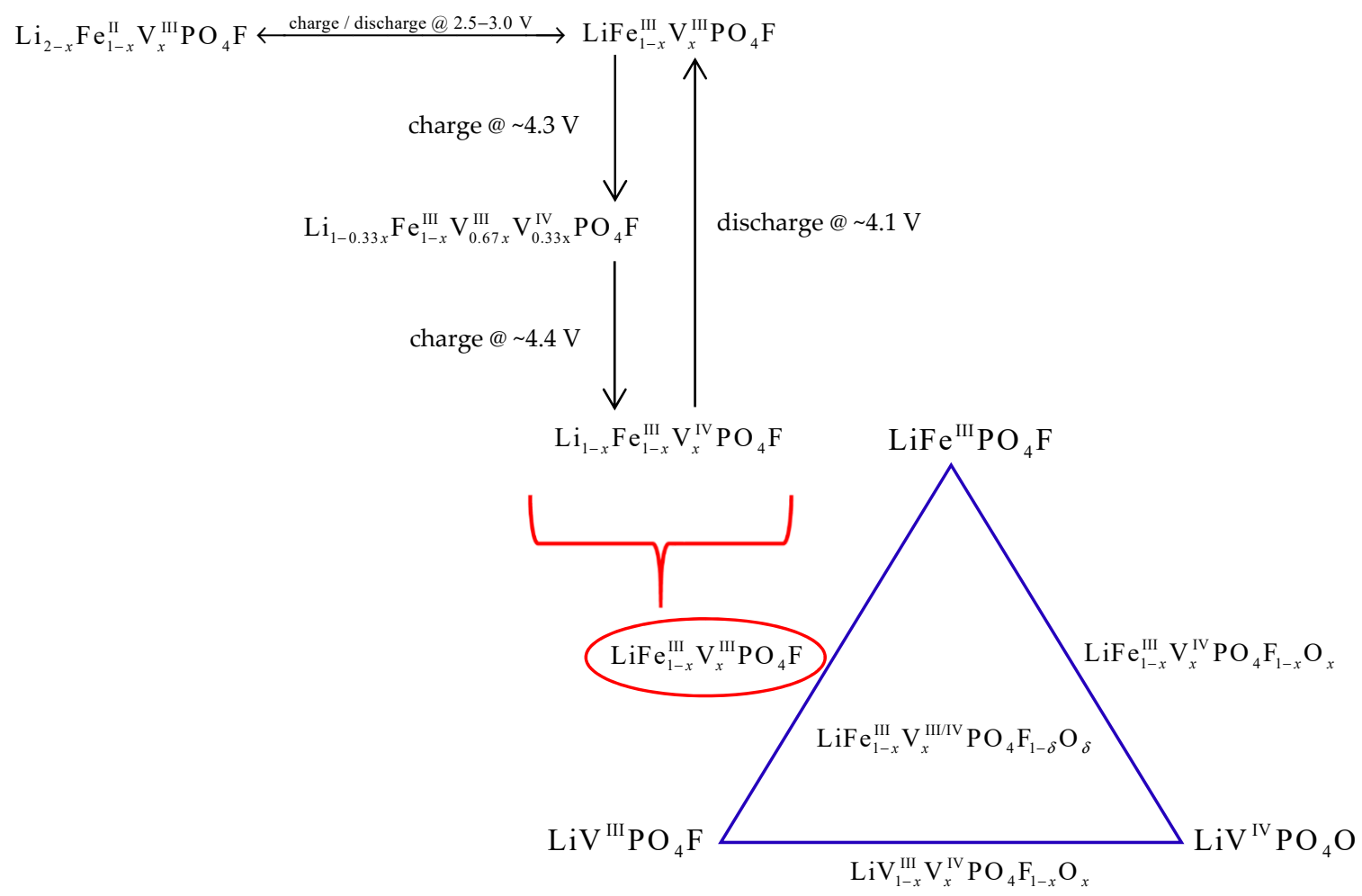

Figure 6. Total reactions in $\mathrm{LiFe}_{1-x} \mathrm{~V}_{x} \mathrm{PO}_{4} \mathrm{~F}(0 \leq x \leq 1)$ cells.

Galvanostatic charge/discharge tests are to understand redox couples and examine the presence of multiple phases. Figure 7 shows the initial and second charge/discharge profiles of $\mathrm{LiFe}_{1-x} \mathrm{~V}_{x} \mathrm{PO}_{4} \mathrm{~F}$ $(0 \leq x \leq 1)$ cells at $0.1 \mathrm{C}$. The galvanostatic tests do not show two separate voltage plateaus on charges around $2.0-4.5 \mathrm{~V}$ because of their higher scan rate $(0.1 \mathrm{C})$ than the reported $(0.02 \mathrm{C}[7,11])$, and the lower resolution than $\mathrm{CV}$ tests (Figures 4 and 5). A flat plateau at $\sim 2.7 \mathrm{~V}$ is assigned to $\mathrm{Fe}^{2+/ 3+}$ couple and the plateau at $\sim 4.2 \mathrm{~V}$ to $\mathrm{V}^{3+/ 4+}$ couple. The additional redox plateau at $\sim 3.4 \mathrm{~V}$ in $\mathrm{LiFe}_{0.5} \mathrm{~V}_{0.5} \mathrm{PO}_{4} \mathrm{~F}$ sample is assigned to $\mathrm{Fe}^{2+/ 3+}$ couple for $\mathrm{LiFePO}_{4}$ impurity, consistent with the XRD and CV results (Figures 1 and 4). Noteworthy is the $\mathrm{Li}^{+}$-extraction/insertion behavior. In regions of 2.0-3.0 $\mathrm{V}$ and 3.0-4.5 V, sloping charge/discharge profiles were observed for all of the $\mathrm{LiFe}_{1-x} \mathrm{~V}_{x} \mathrm{PO}_{4} \mathrm{~F}$ solid-solution samples while $0<x<1$. This indicates a single-phase behavior [24-26,51] which is different from the two-phase behavior for the end-members ( $x=0$ or 1$)$. 


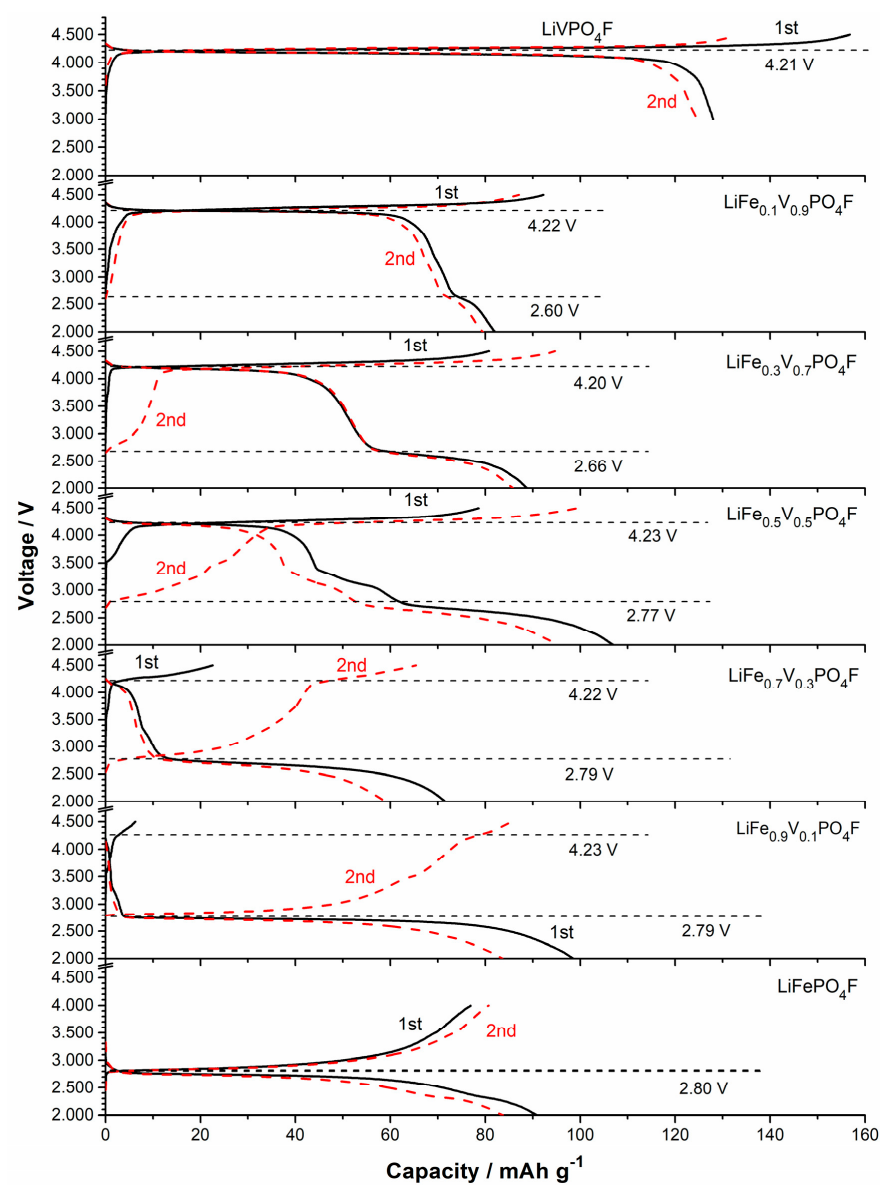

Figure 7. The initial and second charge/discharge profiles of $\mathrm{LiFe}_{1-x} \mathrm{~V}_{x} \mathrm{PO}_{4} \mathrm{~F}(x=0,0.1,0.3,0.5,0.7,0.9$, 1) cells at $0.1 \mathrm{C}$.

\subsection{Li-Ion Diffusion Behavior}

To fully understand the electrochemical reactions occurring during $\mathrm{Li}^{+}$-extraction/insertion process in $\mathrm{LiFe}_{1-x} \mathrm{~V}_{x} \mathrm{PO}_{4} \mathrm{~F}(0 \leq x \leq 1)$ cathodes, galvanostatic intermittent titration technique (GITT) measurements were carried out to evaluate the Li-ion diffusion behavior (Figures 8 and 9). Figure S3 shows a scheme for a GITT measurement.

Diffusion coefficient of lithium ions $\left(D_{\mathrm{Li}^{+}}\right.$, in $\left.\mathrm{cm}^{2} \mathrm{~s}^{-1}\right)$ is calculated based on Equation (5) derived by Weppner et al. [52]:

$$
D_{\mathrm{Li}^{+}}=4 / \pi\left(V_{M} /(S F)\right)^{2}\left(I_{0}\left(\delta E_{S} / y\right) /\left(\delta E / \delta t^{1 / 2}\right)\right)^{2} \text { at } \mathrm{t}<<\tau,
$$

where $S$ is the contact area between the sample and electrolyte $\left(\mathrm{cm}^{2} \mathrm{~g}^{-1}\right)$. In this work, it is calculated from the mean diameter of approximately-spherical grains determined by SEM (Figure 2). The corresponding $S$ values of samples are $8.87 \times 10^{4}\left(\mathrm{LiFePO}_{4} \mathrm{~F}\right), 1.80 \times 10^{4}\left(\mathrm{LiFe}_{0.5} \mathrm{~V}_{0.5} \mathrm{PO}_{4} \mathrm{~F}\right), 1.81 \times 10^{4}$ $\left(\mathrm{LiFe}_{0.3} \mathrm{~V}_{0.7} \mathrm{PO}_{4} \mathrm{~F}\right)$ and $3.66 \times 10^{4} \mathrm{~cm}^{2} \mathrm{~g}^{-1}\left(\mathrm{LiVPO}_{4} \mathrm{~F}\right)$, respectively. This is a suitable choice since $c . f$. errors would be introduced from the residual carbon when using the Brunauer-Emmett-Teller (BET) specific surface area, or from the cathode-in-electrolyte system when using the electrode geometric area. Thus, calculation results may cause a big difference on about several orders of magnitude, but the general trend of $D_{\mathrm{Li}^{+}}$will be the same [53-55]. $V_{M}$ is the molar volume of sample $\left(\mathrm{cm}^{3} \mathrm{~mol}^{-1}\right), F$ is the Faraday constant $\left(9.64853 \times 10^{4} \mathrm{C} \mathrm{mol}^{-1}\right)$, and $I_{0}$ is the pulse current $\left(\mathrm{A} \mathrm{g}^{-1}\right) . \delta E_{s} / \delta y$ is the slope of quasi-equilibrium open-circuit voltage $(\mathrm{OCV})(\mathrm{V})$ as a function of $\mathrm{Li}^{+}$-extraction content $y . \delta E / \delta t^{1 / 2}$ is the slope of the initial transient voltage change as a function of the square root of time $\left(\mathrm{V} \mathrm{s}^{-1 / 2}\right)$. The equation is valid for times shorter than the diffusion time $\tau=(\pi d / 2)^{2} / D_{\mathrm{Li}^{+}}$, where $d$ is the average 
diameter of grains [54]. If the arithmetical units of $D_{\mathrm{Li}^{+}}$were in $\mathrm{m}^{2} \mathrm{~s}^{-1}$, those of $S$ should be in $\mathrm{m}^{2} \mathrm{~g}^{-1}$ and $V_{M}$ in $\mathrm{m}^{3} \mathrm{~mol}^{-1}$ simultaneously.

Figure 8 shows the independent (Figure 8a) and overlaid (Figure 8b) curves of voltage as a function of $\mathrm{Li}^{+}$-extraction content $y$ under load and rest by GITT measurements in $\mathrm{Li}_{2-x-y} \mathrm{Fe}_{1-x}^{\mathrm{II}} \mathrm{V}_{x}^{\mathrm{III}} \mathrm{PO}_{4} \mathrm{~F}$ $(0 \leq x \leq 1 ; 0 \leq y \leq 1)$. Here, the nearly flat region indicates the voltage measured during charging (load), while relaxation spikes at a given state of charge (SOC) (i.e., $\mathrm{Li}^{+}$-extraction content $y$ ) indicate the change in voltage during relaxation or equilibration. The equilibrium OCVs for $\mathrm{Fe}^{2+/ 3+}$ couples in $\mathrm{LiFePO}_{4} \mathrm{~F}$ and $\mathrm{V}^{3+/ 4+}$ couples in $\mathrm{LiVPO}_{4} \mathrm{~F}$ reveal nearly flat potentials on $2.78 \mathrm{~V}$ and $4.24 \mathrm{~V}$, respectively. This means a two-phase reaction mechanism. The $\mathrm{LiFePO}_{4} \mathrm{~F}$ sample exhibits higher over-voltage (longer spikes) than the $\mathrm{LiVPO}_{4} \mathrm{~F}$, indicating its larger polarization and slower equilibration [56]. The OCV profiles of $\mathrm{LiFe}_{1-x} \mathrm{~V}_{x} \mathrm{PO}_{4} \mathrm{~F}$ solid-solution samples $(0<x<1)$, especially for those with $x=0.3$, 0.5 and 0.7 , show a sloping region on going from $\mathrm{Fe}^{2+/ 3+}$ to $\mathrm{V}^{3+/ 4+}$ redox couples. This indicates a single-phase reaction mechanism $[25,32,56]$.

Figures S4-S7 show GITT curves of the quasi-equilibrium OCVs as a function of time, or as a function of $\mathrm{Li}^{+}$-extraction content $y$, plots of the slope of quasi-equilibrium OCVs as a function of $\mathrm{Li}^{+}$-extraction content $y\left(\delta E_{S} / \delta y\right)$, and plots of the slope of initial transient voltage change as a function of the square root of time $\left(\delta E / \delta t^{1 / 2}\right)$, in $\mathrm{Li}_{1-y} \mathrm{Fe}_{1-x}^{\mathrm{III}} \mathrm{V}_{x}^{\mathrm{III}} \mathrm{PO}_{4} \mathrm{~F}$ (i.e., $\mathrm{Li}_{2-x-y} \mathrm{Fe}_{1-x}^{\mathrm{II}} \mathrm{V}_{x}^{\mathrm{III}} \mathrm{PO}_{4} \mathrm{~F}$ with $x=0,0.5,0.7,1)$. Figure 9 shows plots of diffusion coefficients $D_{\mathrm{Li}^{+}}$obtained by GITT as a function of $\mathrm{Li}^{+}$-extraction content $y$. They present disordered " $W$ " or " $U$ " shapes for extraction/insertion, similar to those reported [53].
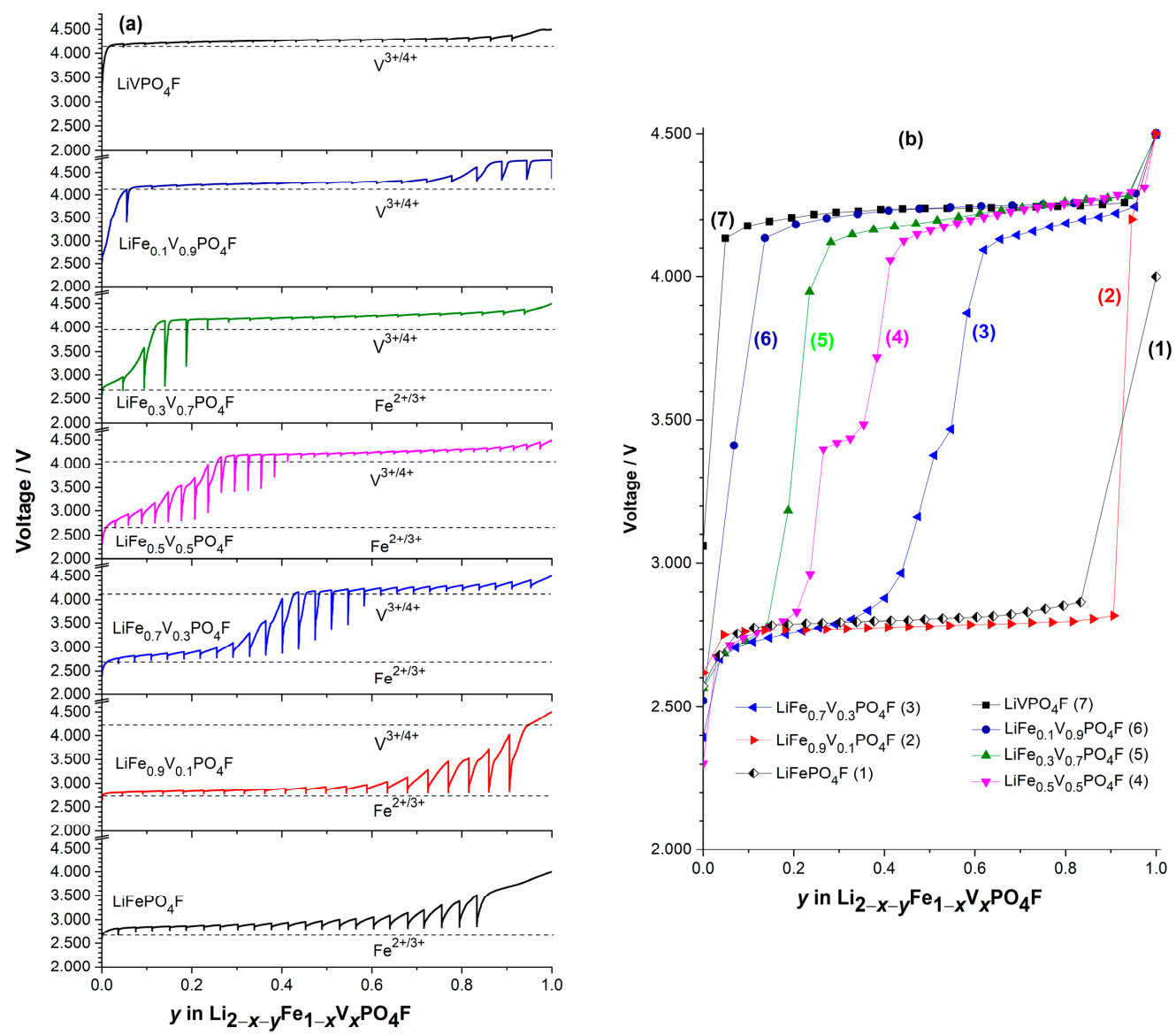

Figure 8. The independent (a) and overlaid (b) curves of voltage as a function of $\mathrm{Li}^{+}$-extraction content $y$ under load and rest by galvanostatic intermittent titration technique (GITT) measurements in $\mathrm{Li}_{2-x-y} \mathrm{Fe}_{1-x}^{\mathrm{II}} \mathrm{V}_{x}^{\mathrm{III}} \mathrm{PO}_{4} \mathrm{~F}(0 \leq x \leq 1 ; 0 \leq y \leq 1)$. 
The obtained $D_{\mathrm{Li}^{+}}$values vary from $\sim 10^{-17}$ to $\sim 10^{-12} \mathrm{~cm}^{2} \mathrm{~s}^{-1}\left(\mathrm{LiFePO}_{4} \mathrm{~F}\right), \sim 10^{-17}$ to $10^{-11} \mathrm{~cm}^{2} \mathrm{~s}^{-1}\left(\mathrm{LiFe}_{0.5} \mathrm{~V}_{0.5} \mathrm{PO}_{4} \mathrm{~F}\right), \sim 10^{-15}$ to $\sim 5 \times 10^{-11} \mathrm{~cm}^{2} \mathrm{~s}^{-1}\left(\mathrm{LiFe}_{0.3} \mathrm{~V}_{0.7} \mathrm{PO}_{4} \mathrm{~F}\right)$ and $\sim 10^{-17}$ to $\sim 10^{-10} \mathrm{~cm}^{2} \mathrm{~s}^{-1}\left(\mathrm{LiVPO}_{4} \mathrm{~F}\right)$, respectively. Each of them has a minimum which was caused by strong attractive interactions between the $\mathrm{Li}^{+}$-extraction/insertion species and the host matrix [54]. As the doped V-content $x$ increases from 0 to 1 , the upper-limit value of $D_{\mathrm{Li}^{+}}$increases 1-2 orders of magnitude. If the geometric area of the electrode was used as the contact area $(S)[25,55]$, diffusion coefficients would increase 2-3 orders of magnitude for samples in this work. It indicates that $\mathrm{LiFe}_{1-x} \mathrm{~V}_{x} \mathrm{PO}_{4} \mathrm{~F}$ $(0<x<1)$ solid solutions have comparable electrochemical activities with their end-members $(x=0$ or 1), while redox potentials can be tuned within a wide range, 2.0-4.5 V, by cation ( $\mathrm{V}$ for Fe or Fe for $\mathrm{V}$ ) substitutions. This makes them attractive cathode candidates of high specific-energy Li-ion batteries.
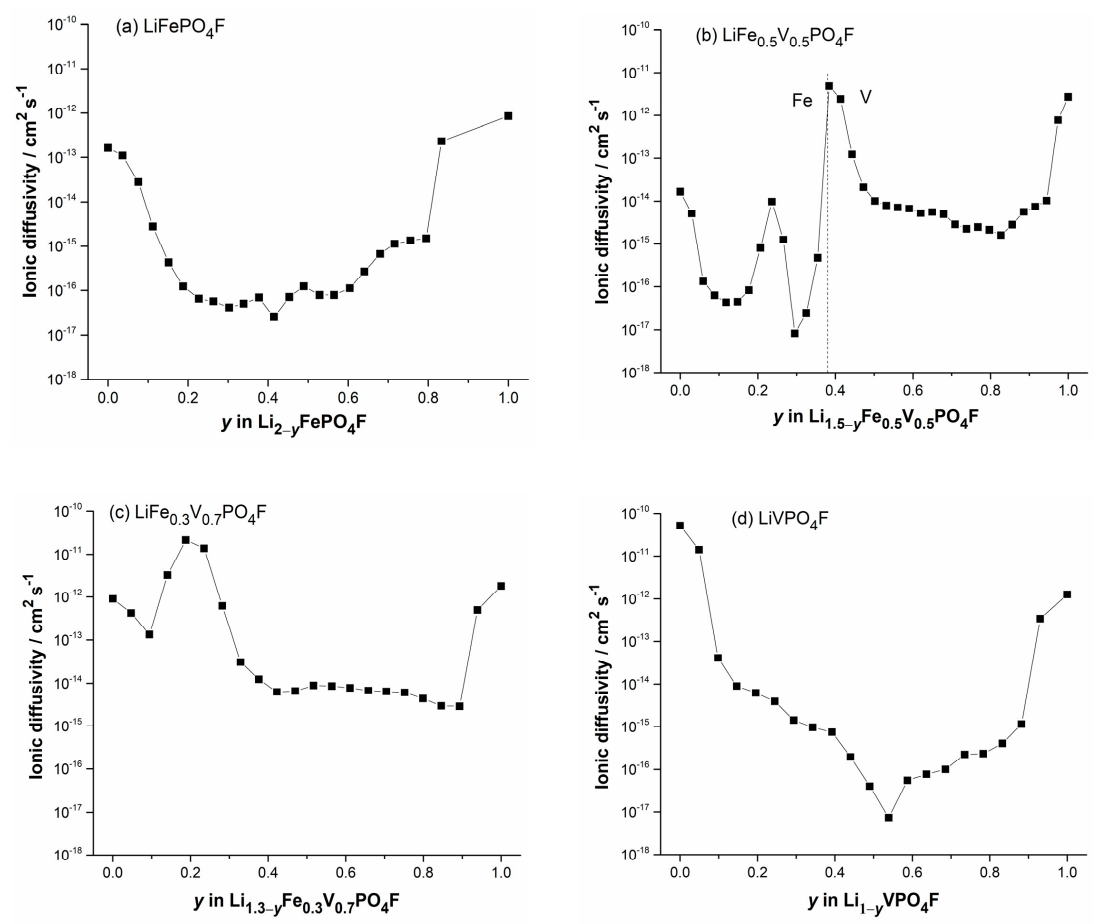

Figure 9. Plots of diffusion coefficients obtained by GITT as a function of $\mathrm{Li}^{+}$-extraction content $y$ in $\mathrm{Li}_{2-x-y} \mathrm{Fe}_{1-x}^{\mathrm{II}} \mathrm{V}_{x}^{\mathrm{III}} \mathrm{PO}_{4} \mathrm{~F}(0 \leq y \leq 1)$ with $x=0(\mathbf{a}), x=0.5(\mathbf{b}), x=0.7$ (c) and $x=1(\mathbf{d})$.

\section{Discussion}

Figure 10 shows shifts in midpoints of anodic $\left(\mathrm{Li}^{+}\right.$-extraction) and cathodic $\left(\mathrm{Li}^{+}\right.$-insertion) peaks for $\mathrm{Fe}^{2+/ 3+}$ and $\mathrm{V}^{3+/ 4+}$ couples, exported from Figure 4 , as a function of $\mathrm{V}$-content $x$ in $\mathrm{LiFe}_{1-x} \mathrm{~V}_{x} \mathrm{PO}_{4} \mathrm{~F}$ $(0 \leq x \leq 1)$. As mentioned in Section 2.4, there exists two anodic peaks assigned to $\mathrm{V}^{3+/ 4+}$ redox couple when $0<x \leq 1$, and the separation of anodic peaks is $\sim 0.07 \mathrm{~V}$. For simplicity, one midpoint was calculated from a cathodic peak and its corresponding higher-potential anodic peak. As the V-content $x$ increases, a downward shift in the redox potential of $\mathrm{Fe}^{2+/ 3+}$ couple was observed. However, there was hardly any shift for $\mathrm{V}^{3+/ 4+}$ couple. These are different significantly from those in the reported $\mathrm{Li}_{1-y}^{\prime} M_{y}^{\prime} \mathrm{PO}_{4}\left(M^{\prime}, M^{\prime \prime}=\mathrm{Mn}, \mathrm{Fe}, \mathrm{Co}\right)$, in which potentials increasing of lower potential (LP)-couples is always associated with potentials decreasing of high potential (HP)-couples [56-58], compared to potentials of the pristine end-members.

Redox energies of cations can be tuned through the inductive effect introduced by a counter cation substitution $[24,25,56,59]$ in $\mathrm{LiFe}_{1-x}^{\mathrm{III}} \mathrm{V}_{x}^{\mathrm{III}} \mathrm{PO}_{4} \mathrm{~F}(0<x<1)$ solid-solution cathodes. If the polyanion $\left(\mathrm{PO}_{4} \mathrm{~F}\right)$ was fixed, the change in the covalency of $M-\mathrm{O}_{4} \mathrm{~F}_{2}$ bonds $\left(M=\mathrm{Fe}_{1-x} \mathrm{~V}_{x}\right)$ could be caused by the following:

(i) Change in the electronegativity of $M$ : The substitution of a less electronegative (more electropositive) $\mathrm{V}^{3+}$ for $\mathrm{Fe}^{3+}$ is expected to increase the $\mathrm{Fe}-\mathrm{O}_{4} \mathrm{~F}_{2}$ covalency due to the inductive 
effect (weaker $\mathrm{V}-\mathrm{O}_{4} \mathrm{~F}_{2}$ covalency strengthens the $\mathrm{Fe}-\mathrm{O}_{4} \mathrm{~F}_{2}$ covalency), and raise the $\mathrm{Fe}^{2+/ 3+}$ redox energy, thereby decreasing the redox potential of $\mathrm{Fe}^{2+/ 3+}$ couple, in accord with what we observe in Figure 10. Similarly, the substitution of a more electronegative $\mathrm{Fe}^{3+}$ for $\mathrm{V}^{3+}$ would be expected to decrease the $\mathrm{V}-\mathrm{O}_{4} \mathrm{~F}_{2}$ covalency, lower the $\mathrm{V}^{3+/ 4+}$ redox energy, and increase the redox potential of the $\mathrm{V}^{3+/ 4+}$ couple [56-58]. This is not in accord with what we observe in Figure 10.

(ii) Change in the $M-\mathrm{O}_{4} \mathrm{~F}_{2}$ bond length: The covalency contraction effect originates from the relative contraction of cation-anion distances in two different isotypic compounds with different electronegativity [35]. As stated before, the $\mathrm{V}^{3+}\left(r_{\mathrm{V}^{3+}}=0.640 \AA\right)$ and $\mathrm{Fe}^{3+}\left(r_{\mathrm{Fe}^{3+}, \mathrm{HS}}=0.645 \AA\right)$ have close effective ionic radii $(\mathrm{CN}=6)[3,34,35]$. In a high spin (HS) state, the covalency contraction effect and crystal field effect play collectively a dominant role on the $\mathrm{Fe}^{2+}\left(r_{\mathrm{Fe}^{2+}, \mathrm{HS}}=0.780 \AA\right)$ and $\mathrm{Fe}^{3+}\left(r_{\mathrm{Fe}^{3+}, \mathrm{HS}}=0.645 \AA\right)$, and as a result their radii are close to the $\mathrm{V}^{2+}\left(r_{\mathrm{V}^{2+}}=0.79 \AA\right)$ and $\mathrm{V}^{3+}$ $\left(r_{\mathrm{V}^{3+}}=0.640 \AA\right)$, respectively. But in a low spin (LS) state, the covalency contraction effect plays a dominant role on the $\mathrm{Fe}^{2+}\left(r_{\mathrm{Fe}^{2+}, \mathrm{LS}}=0.61 \AA\right)$ and $\mathrm{Fe}^{3+}\left(r_{\mathrm{Fe}^{3+}, \mathrm{LS}}=0.55 \AA\right)$, and as result their radii are smaller than the $\mathrm{V}^{2+}\left(r_{\mathrm{V}^{2+}}=0.79 \AA\right)$ and $\mathrm{V}^{3+}\left(r_{\mathrm{V}^{3+}}=0.640 \AA\right)$, respectively $[3,34,35]$. The substitution of $\mathrm{V}^{3+}\left(r_{\mathrm{V}^{3+}}=0.640 \AA\right)$ for $\mathrm{Fe}^{3+}\left(r_{\mathrm{Fe}^{3+}, \mathrm{HS}}=0.645 \AA\right)$ with close effective ionic radii does not change the $M-\mathrm{O}_{4} \mathrm{~F}_{2}$ bond length (therefore it does not change the $\mathrm{Fe}-\mathrm{O}_{4} \mathrm{~F}_{2}$ or $\mathrm{V}-\mathrm{O}_{4} \mathrm{~F}_{2}$ covalency), indicating that redox energies/potentials of $\mathrm{Fe}^{2+/ 3+}$ and $\mathrm{V}^{3+/ 4+}$ couples would not change which correlates to the inductive effect [56-58]. This identifies with what we observe in Figure 10. We do not support that the $\mathrm{Fe}^{3+/ 4+}$ couple exists stably in range of 2.0-4.5 V $[4,26,60]$.

Therefore, we can conclude that the electronegativity of $M$ plays a dominant role compared to the $M-\mathrm{O}_{4} \mathrm{~F}_{2}$ bond length for the redox potential of $\mathrm{Fe}^{2+/ 3+}$ couple in $\mathrm{LiFe}_{1-x}^{\mathrm{III}} \mathrm{V}_{x}^{\mathrm{III}} \mathrm{PO}_{4} \mathrm{~F}$ solid-solution cathodes $\left(M=\mathrm{Fe}_{1-x} \mathrm{~V}_{x} ; 0<x<1\right)$. But for the redox potential of $\mathrm{V}^{3+/ 4+}$ couple, the $M-\mathrm{O}_{4} \mathrm{~F}_{2}$ bond length plays a dominant role in controlling the redox energy of cation $\mathrm{V}$.

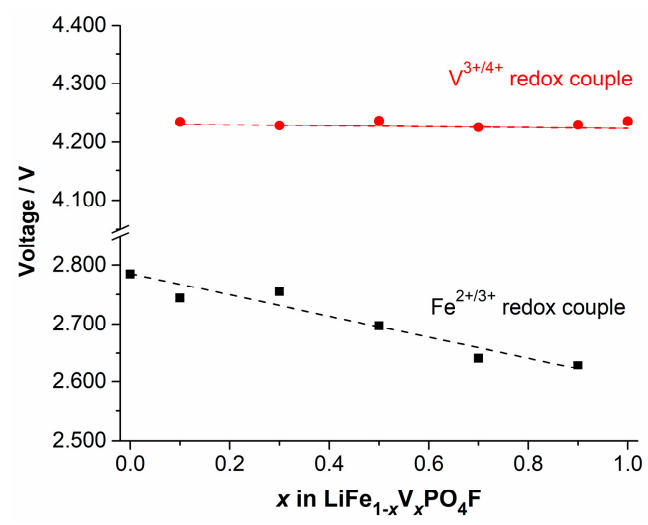

Figure 10. Shifts in midpoints of anodic ( $\mathrm{Li}^{+}$-extraction) and cathodic ( $\mathrm{Li}^{+}$-insertion) peaks for $\mathrm{Fe}^{2+/ 3+}$ and $\mathrm{V}^{3+/ 4+}$ couples, exported from Figure 4 , as a function of $\mathrm{V}$-content $x$ in $\mathrm{LiFe}_{1-x} \mathrm{~V}_{x} \mathrm{PO}_{4} \mathrm{~F}(0 \leq x \leq 1)$.

It is likely there is also a continuous downshift for the $\mathrm{Fe}^{2+/ 3+}$ couple shown in OCV profiles (Figures 8 and 9) with increasing substitution of $\mathrm{V}^{3+}$ for $\mathrm{Fe}^{3+}$, while there is no shift for the $\mathrm{V}^{3+/ 4+}$ couple with increasing substitution of $\mathrm{Fe}^{3+}$ for $\mathrm{V}^{3+}$ in $\mathrm{LiFe}_{1-x} \mathrm{~V}_{x} \mathrm{PO}_{4} \mathrm{~F}(0 \leq x \leq 1)$, to support results of $\mathrm{CV}$ measurements (Figure 4). However, we do not now adopt the idea because all GITT measurements in this work started only from the fully-discharged state. It also needs to start from the fully-charged state $\left(\mathrm{Li}_{1-x} \mathrm{Fe}_{1-x}^{\mathrm{III}} \mathrm{V}_{x}^{\mathrm{IV}} \mathrm{PO}_{4} \mathrm{~F}\right)$ at $4.5 \mathrm{~V}$ toward cathodic direction with identical relaxation conditions to confirm the measured OCVs including negligible kinetic effect [57]. Research is underway and will be reported elsewhere.

\section{Materials and Methods}

The $\mathrm{VPO}_{4}$ powder was pre-synthesized by a hydrothermal route using raw materials of $\mathrm{H}_{3} \mathrm{PO}_{3}$ (99\% wt, Sinopharm Chem. Reag. Co. Ltd., Shanghai, China), $\mathrm{V}_{2} \mathrm{O}_{5}(99 \%$ wt, Energy Chem. Co. 
Ltd., Shanghai, China) and $\mathrm{H}_{2} \mathrm{O}$. Firstly, $\mathrm{H}_{3} \mathrm{PO}_{3}$ was dissolved in $\mathrm{H}_{2} \mathrm{O}$, then $\mathrm{V}_{2} \mathrm{O}_{5}$ was added to the solution under vigorous stirring. Reagents were placed in an autoclave, heated to $160^{\circ} \mathrm{C}$, dwelled for $6 \mathrm{~h}$ and cooled inside to room temperature (RT). Secondly, the intermediate product from the autoclave was dried in a vacuum oven at $80{ }^{\circ} \mathrm{C}$ for $4 \mathrm{~h}$ and then calcined at $800{ }^{\circ} \mathrm{C}$ for $5 \mathrm{~h}$ under argon in a tube furnace. The hydrothermal-synthesis process is: $\mathrm{H}_{3} \mathrm{PO}_{3}+\mathrm{V}_{2} \mathrm{O}_{5}+\mathrm{H}_{2} \mathrm{O} \stackrel{160}{\stackrel{\circ}{\longrightarrow} \mathrm{C}, 6 \mathrm{~h}}$

$\mathrm{VPO}_{4} \cdot x \mathrm{H}_{2} \mathrm{O} \quad 800 \stackrel{{ }^{\circ} \mathrm{C}, 5}{\longrightarrow} \mathrm{h}, \mathrm{Ar} \quad \mathrm{VPO}_{4} . \quad \mathrm{LiFe}_{1-x} \mathrm{~V}_{x} \mathrm{PO}_{4} \mathrm{~F}(x=0,0.1,0.3,0.5,0.7,0.9,1)$ powders were then obtained by mixing the hydrothermal-synthesized $\mathrm{VPO}_{4}$, commercial $\mathrm{FePO}_{4}(99 \%$ wt, Mianyang Tianming New Energy Technol. Co. Ltd., Mianyang, China) and LiF (99.9\% wt, Aladdin Chem. Reag. Co. Ltd., Shanghai, China), followed by pelletizing, calcining at $625^{\circ} \mathrm{C}$ for $1.5 \mathrm{~h}$ under argon and grinding $[4,26,33]$.

$\mathrm{LiFe}_{1-x} \mathrm{~V}_{x} \mathrm{PO}_{4} \mathrm{~F}(x=0,0.1,0.3,0.5,0.7,0.9,1)$ electrodes and cells were prepared using the same method as pure $\mathrm{LiFePO}_{4} \mathrm{~F} / \mathrm{LiVPO} \mathrm{F}_{4} \mathrm{~F}$ ones [4,26,33]. $\mathrm{LiFe}_{1-x} \mathrm{~V}_{x} \mathrm{PO}_{4} \mathrm{~F}$ powders, super $\mathrm{P}$ (conductive carbon) and binder (polyvinylidene fluoride, $\mathrm{PVDF}$ ) were mixed to form a slurry by using $\mathrm{N}$-methyl-pyrrolidone (NMP) as the solvent $\left(\mathrm{LiFe}_{1-x} \mathrm{~V}_{x} \mathrm{PO}_{4} \mathrm{~F}: \mathrm{C}: \mathrm{PVDF}=8: 1: 1, \% \mathrm{wt}\right)$. The aluminum foil casted by the slurry was then vacuum-dried at $120^{\circ} \mathrm{C}$ for $12 \mathrm{~h}$, roller-pressed and cut into discs of $15 \mathrm{~mm}$ diameter $\left(1.767 \mathrm{~cm}^{2}\right)$. The loading density of active material was $1.2-3.4 \times 10^{-3} \mathrm{~g} \mathrm{~cm}^{-2}$ approximately. The electrolyte was $1 \mathrm{M} \mathrm{LiPF}_{6}$ dissolved in a mixture of ethylene carbonate (EC) and dimethyl carbonate (DMC) (1:1, \% vol). The polypropylene film (Celgard 2400) was used as the separator and lithium foil as the counter and reference electrodes. The lithium-ion rechargeable (LIR) 2025 coin-type cells were assembled in an argon-filled glove box (Etelux Lab2000, Beijing, China).

Elaborative phase determination $\left(8^{\circ} \leq 2 \theta \leq 100^{\circ}\right)$ was carried out by $X$-ray powder diffraction (XRD) using $\mathrm{Cu} K_{\alpha}$ radiation $\left(\lambda_{\alpha 1}=1.54060 \AA, 40 \mathrm{kV}, 40 \mathrm{~mA}\right)$ in flat plate $\theta / 2 \theta$ geometry at a step size of $0.01943^{\circ}$ /step and a scan speed of $0.01203^{\circ}$ /s (D8 Adv., Bruker Co. Ltd., Karlsruhe, Germany). Testing conditions included a divergence slit of $1.0 \mathrm{~mm}$, an antiscatter slit of $6.94 \mathrm{~mm}$, a primary soller slit of $2.5^{\circ}$, a second soller slit of $2.5^{\circ}$ and a detector slit of $12.21 \mathrm{~mm}$. Structure refinements were performed by the Rietveld method implemented in GSAS/EXIGUI Revision 1251 software [61] using the model $\mathrm{Li}_{2 i}(\mathrm{Fe} 1, \mathrm{~V} 1)_{1 a}(\mathrm{Fe} 2, \mathrm{~V} 2)_{1 b}\left\{\mathrm{P}_{2 i}\left[\mathrm{O}_{2 i}\right]_{4}\right\} \mathrm{F}_{2 i}$ based on the $\mathrm{LiFe}_{0.5} \mathrm{~V}_{0.5} \mathrm{PO}_{4} \mathrm{~F}$ structure [25] which has only one crystallographic lithium site $[7,11]$, contrary to the previous viewpoints $[6,36,48]$. Valence states of $\mathrm{Fe} / \mathrm{V}$ components in $\mathrm{FePO}_{4}, \mathrm{VPO}_{4}$ and $\mathrm{LiFe}_{1-x} \mathrm{~V}_{x} \mathrm{PO}_{4} \mathrm{~F}(0 \leq x \leq 1)$ powders were determined by $\mathrm{X}$-ray photoelectron spectra (XPS) using a Multilab 2000 spectrometer (VG Inc., Waltham, MA, USA) equipped with a focused monochromatized $\mathrm{Al} K_{\alpha} \mathrm{X}$-ray source $(h v=1486.6 \mathrm{eV})$. All the obtained binding energy (BE) values were calibrated using the photoemission line $\mathrm{C} 1 \mathrm{~s}$ at $284.8 \mathrm{eV}$. The microstructure and compositions of samples were characterized by a field-emission scanning electron microscope (FESEM; SU-8020, Hitachi Ltd., Tokyo, Japan) equipped with an X-ray spectrometer for energy dispersive spectroscopy (Bruker EDS QUANTAX, Karlsruhe, Germany).

To evaluate electrochemical properties of $\mathrm{LiFe}_{1-x} \mathrm{~V}_{x} \mathrm{PO}_{4} \mathrm{~F}(0 \leq x \leq 1)$ cathodes, cyclic voltammetry (CV) measurements were carried out at RT with sweep rates of $0.1 / 0.2 / 0.3 / 0.4 / 0.5 \mathrm{mV} \mathrm{s}^{-1}$, in the range of 2.0-4.5 V (vs. $\mathrm{Li}_{/} / \mathrm{Li}^{+}$) for $\mathrm{Fe}^{2+/ 3+}$ and $\mathrm{V}^{3+/ 4+}$ couples, $2.0-3.6 \mathrm{~V}$ for $\mathrm{Fe}^{2+/ 3+}$ couple and 3.0-4.5 $\mathrm{V}$ for $\mathrm{V}^{3+/ 4+}$ couple, using a CHI660e electrochemical workstation (Shanghai Chenhua Instr. Co. Ltd., Shanghai, China). Galvanostatic charge/discharge tests $(0.1 \mathrm{C})$ were performed at $\mathrm{RT}$, in the range of $2.0-4.5 \mathrm{~V}$ for $\mathrm{LiFe}_{1-x} \mathrm{~V}_{x} \mathrm{PO}_{4} \mathrm{~F}(0<x<1), 2.0-4.0 \mathrm{~V}$ for $\mathrm{LiFePO}_{4} \mathrm{~F}$ and 3.0-4.5 $\mathrm{V}$ for $\mathrm{LiVPO}_{4} \mathrm{~F}$, using a CT2001A Land battery testing system (Wuhan Land Electronics Co. Ltd., Wuhan, China). Galvanostatic intermittent titration technique (GITT) measurements started from the fully-discharged state $\left(\mathrm{Li}_{2-x} \mathrm{Fe}_{1-x}^{\mathrm{II}} \mathrm{V}_{x}^{\mathrm{III}} \mathrm{PO}_{4} \mathrm{~F}\right)$ at $2.0 \mathrm{~V}$, which realized after the cell discharged for $24 \mathrm{~h}$ at $0.05 \mathrm{C}$, toward anodic direction with intermittent of $5 \%$ state of charge ( $5 \% \mathrm{SOC}$, i.e., $0.05 \mathrm{Li}^{+}$-extraction). The charging at $0.05 \mathrm{C}$ was followed after $3 \mathrm{~h}$ relaxation for equilibrium at each open-circuit voltage (OCV) measuring points. GITT measurements proceeded until reaching the fully-charged state $\left(\mathrm{Li}_{1-x} \mathrm{Fe}_{1-x}^{\mathrm{III}} \mathrm{V}_{x}^{\mathrm{IV}} \mathrm{PO}_{4} \mathrm{~F}\right)$ at $4.5 \mathrm{~V}$. 


\section{Conclusions}

In this work, tavorite triclinic-structured $\mathrm{LiFe}_{1-x} \mathrm{~V}_{x} \mathrm{PO}_{4} \mathrm{~F}(x=0,0.1,0.3,0.5,0.7,0.9$ and 1) solid-solution powders, the related cathodes and Li-ion batteries were prepared and characterized.

The systematic variations in lattice parameters and unit cell volumes via XRD Rietveld refinements confirm the formation of homogeneous solid solutions, which originate from the substitution of $\mathrm{V}^{3+}$ for $\mathrm{Fe}^{3+}$ with close effective ionic radii. The valence states of $\mathrm{Fe}^{3+} / \mathrm{V}^{3+}$ were identified by XPS and a homogeneous distribution of $\mathrm{Fe} / \mathrm{V} / \mathrm{P} / \mathrm{F}$ components by SEM/EDS.

A single-phase behavior is confirmed strongly by analyzing the broad shape of cyclic voltammetry (CV) peaks, sloping charge/discharge profiles and sloping open-circuit voltage (OCV) profiles in $\mathrm{LiFe}_{1-x} \mathrm{~V}_{x} \mathrm{PO}_{4} \mathrm{~F}$ solid-solution cathodes. As the vanadium content $x$ increases, a downward shift in the redox potential of $\mathrm{Fe}^{2+/ 3+}$ couple was observed in $\mathrm{CV}$ curves. However, there was hardly any shift for the $\mathrm{V}^{3+/ 4+}$ couple. The electronegativity of $M\left(M=\mathrm{Fe}_{1-x} \mathrm{~V}_{x}\right)$ plays a dominant role compared to the $M-\mathrm{O}_{4} \mathrm{~F}_{2}$ bond length for the redox potential of $\mathrm{Fe}^{2+/ 3+}$ couple. Yet for the redox potential of $\mathrm{V}^{3+/ 4+}$ couple, the $M-\mathrm{O}_{4} \mathrm{~F}_{2}$ bond length plays a dominant role. The obtained diffusion coefficient of lithium ions $\left(D_{\mathrm{Li}^{+}}\right)$indicates that $\mathrm{LiFe}_{1-x} \mathrm{~V}_{x} \mathrm{PO}_{4} \mathrm{~F}(0<x<1)$ solid solutions have comparable electrochemical activities with their end-members $(x=0$ or 1$)$.

The mechanism is involved in redox energies of cations which are tuned within a wide range 2.0-4.5 $\mathrm{V}$ in polyanion-type cathodes, through the inductive effect introduced by cation (V for Fe) substitution.

Supplementary Materials: The following are available online at http://www.mdpi.com/1420-3049/24/10/1893/s1, Table S1-S7: Rietveld refined parameters of the tavorite $\mathrm{LiFe}_{1-x} \mathrm{~V}_{x} \mathrm{PO}_{4} \mathrm{~F}(x=0,0.1,0.3,0.5,0.7,0.9$ and 1$)$ structure. Table S8: Comparison of lattice parameters for $\mathrm{LiFe}_{1-x} \mathrm{~V}_{x} \mathrm{PO}_{4} \mathrm{~F}(0 \leq x \leq 1)$ samples and the related publications. Figure S1: The final observed, calculated and difference profiles of the tavorite-structured $\mathrm{LiFePO}_{4} \mathrm{~F}$, $\mathrm{LiFe}_{0.9} \mathrm{~V}_{0.1} \mathrm{PO}_{4} \mathrm{~F}, \mathrm{LiFe}_{0.7} \mathrm{~V}_{0.3} \mathrm{PO}_{4} \mathrm{~F}, \mathrm{LiFe}_{0.5} \mathrm{~V}_{0.5} \mathrm{PO}_{4} \mathrm{~F}, \mathrm{LiFe}_{0.3} \mathrm{~V}_{0.7} \mathrm{PO}_{4} \mathrm{~F}, \mathrm{LiFe}_{0.1} \mathrm{~V}_{0.9} \mathrm{PO}_{4} \mathrm{~F}$ and $\mathrm{LiVPO}_{4} \mathrm{~F}$ via Rietveld refinements. Figure S2: Variations of lattice parameters $(\boldsymbol{a}, \boldsymbol{b}, \boldsymbol{c}, \alpha, \beta$ and $\gamma)$ and unit cell volumes $(V)$ of $\mathrm{LiFe}_{1-x} \mathrm{~V}_{x} \mathrm{PO}_{4} \mathrm{~F}(0 \leq x \leq 1)$ solid solutions. Figure S3: Scheme for a GITT measurement. Figures S4-S7: Curves of the quasi-equilibrium OCVs as a function of time by GITT, or as a function of $\mathrm{Li}^{+}$-extraction content $y$, plots of the slope of quasi-equilibrium OCVs as a function of $\mathrm{Li}^{+}$-extraction content $y\left(\delta E_{s} / \delta y\right)$, and plots of the slope of initial transient voltage change as a function of square root of time $\left(\delta E / \delta t^{1 / 2}\right)$, in $\mathrm{Li}_{1-y} \mathrm{Fe}_{1-x}^{\mathrm{III}} \mathrm{V}_{x}^{\mathrm{III}} \mathrm{PO}_{4} \mathrm{~F}$, i.e., $\mathrm{Li}_{2-x-y} \mathrm{Fe}_{1-x}^{\mathrm{II}} \mathrm{V}_{x}^{\mathrm{III}} \mathrm{PO}_{4} \mathrm{~F}$ with $x=0,0.5,0.7$ and 1 .

Author Contributions: J.-L.Y. performed experiments and wrote the manuscript. S.-H.F. performed part of the experiments. C.Z., Y.Z., J.W. and Q.L. helped do experiments and revise the manuscript. G.-Q.S. conceived the idea and supervised the project. All authors read and approved the final manuscript.

Funding: This research was funded by the State Key Laboratory of Advanced Technology for Materials Synthesis and Processing, WUT, China (Grant No. 2016-KF-4).

Acknowledgments: The authors gratefully acknowledge J.-H. Liu, D. Chen, B. Li, F.-F. Ma, J.-W. Mao and D.-S. Zhao in our group. Additional thanks to Fan in SCUN, B.-L. Wu in GUT and J.-X. Mi in XMU.

Conflicts of Interest: The authors declare no conflicts of interest.

\section{Appendix A}

Further details of crystal structures may be obtained from Cambridge Crystallographic Data Centre (CCDC)/Leibniz Institute for Information Infrastructure (FIZ Karlsruhe) joint deposition and access services (www.ccdc.cam.ac.uk; www.fiz-karlsruhe.de) on quoting the appropriate CSD numbers (G.-Q.S., J.-L.Y., S.-H.F., et al., $\mathrm{LiFe}_{0.3} \mathrm{~V}_{0.7} \mathrm{PO}_{4} \mathrm{~F}$ CSD 1906255 and $\mathrm{LiVPO}_{4} \mathrm{~F}$ CSD 1906256, 28 March 2019).

\section{References}

1. Prabu, M.; Reddy, M.V.; Selvasekarapandian, S.; Subba-Rao, G.V.; Chowdari, B.V.R. Synthesis, impedance and electrochemical studies of lithium iron fluorophosphate, $\mathrm{LiFePO}_{4} \mathrm{~F}$ cathode. Electrochim. Acta 2012, 85, 572-578. [CrossRef]

2. Molenda, J.; Ojczyk, W.; Świerczek, K.; Zajac, W.; Krok, F.; Dygas, J.; Liu, R.S. Diffusional mechanism of deintercalation in $\mathrm{LiFe}_{1-y} \mathrm{Mn}_{y} \mathrm{PO}_{4}$ cathode material. Solid State Ion. 2006, 177, 2617-2624. [CrossRef] 
3. Ramzan, M.; Lebegue, S.; Larsson, P.; Ahuja, R. Structural, magnetic, and energetic properties of $\mathrm{Na}_{2} \mathrm{FePO}_{4} \mathrm{~F}$, $\mathrm{Li}_{2} \mathrm{FePO}_{4} \mathrm{~F}, \mathrm{NaFePO}_{4} \mathrm{~F}$, and $\mathrm{LiFePO}_{4} \mathrm{~F}$ from ab initio calculations. J. Appl. Phys. 2009, 106, 043510. [CrossRef]

4. Chen, D.; Shao, G.-Q.; Li, B.; Zhao, G.-G.; Li, J.; Liu, J.-H.; Gao, Z.-S.; Zhang, H.-F. Synthesis, crystal structure and electrochemical properties of $\mathrm{LiFePO}_{4} \mathrm{~F}$ cathode material for Li-ion batteries. Electrochim. Acta 2014, 147, 663-668. [CrossRef]

5. Padhi, A.; Nanjundaswamy, K.; Masquelier, C.; Okada, S.; Goodenough, J. Effect of structure on the $\mathrm{Fe}^{3+} / \mathrm{Fe}^{2+}$ redox couple in iron phosphates. J. Electrochem. Soc. 1997, 144, 1609-1613. [CrossRef]

6. Barker, J.; Saidi, M.Y.; Swoyer, J.L. Electrochemical insertion properties of the novel lithium vanadium fluorophosphate, $\mathrm{LiVPO}_{4}$ F. J. Electrochem. Soc. 2003, 150, A1394-A1398. [CrossRef]

7. Mba, J.M.A.; Croguennec, L.; Basir, N.I.; Barker, J.; Masquelier, C. Lithium insertion or extraction from/into tavorite-type $\mathrm{LiVPO}_{4} \mathrm{~F}$ : An in situ X-ray diffraction study. J. Electrochem. Soc. 2012, 159, A1171-A1175. [CrossRef]

8. $\quad$ Fan, C.-L.; Wen, Z.; Xiao, R.-F.; Li, Q.-Y.; Gong, Y.; Zeng, T.-T.; Wei, S.; Zhang, X.; Han, S.-C. LiVPO 4 F/C cathode synthesized by a fast chemical reduction method for lithium-ion batteries. Mater. Lett. 2016, 170, 35-38. [CrossRef]

9. Yang, B.; Yang, L. Silver-coated $\mathrm{LiVPO}_{4} \mathrm{~F}$ composite with improved electrochemical performance as cathode material for lithium-ion batteries. J. Phys. Chem. Solids 2015, 87, 228-232. [CrossRef]

10. Yan, H.; Wu, X.; Li, Y. Preparation and characterization of conducting polyaniline-coated $\mathrm{LiVPO}_{4} \mathrm{~F}$ nanocrystals with core-shell structure and its application in lithium-ion batteries. Electrochim. Acta 2015, 182, 437-444. [CrossRef]

11. Mba, J.M.A.; Masquelier, C.; Suard, E.; Croguennec, L. Synthesis and crystallographic study of homeotypic $\mathrm{LiVPO}_{4} \mathrm{~F}$ and $\mathrm{LiVPO}_{4} \mathrm{O}$. Chem. Mater. 2012, 24, 1223-1234. [CrossRef]

12. Li, P.; Wang, P.; Yu, H.; Lin, X.; Shao, L.; Shui, M.; Long, N.; Shu, J. Carbothermal synthesis of $\mathrm{LiVPO}_{4} \mathrm{~F}$ and its structural change in a broad potential range observed by in-situ X-ray diffraction. Ceram. Int. 2015, 41, 10766-10774. [CrossRef]

13. Wang, J.-X.; Wang, Z.-X.; Li, X.-H.; Guo, H.-J.; Wu, X.-W.; Zhang, X.-P.; Xiao, W. $x \mathrm{Li}_{3} \mathrm{~V}_{2}\left(\mathrm{PO}_{4}\right)_{3}$ center dot $\mathrm{LiVPO}_{4} \mathrm{~F} / \mathrm{C}$ composite cathode materials for lithium ion batteries. Electrochim. Acta 2013, 87, 224-229. [CrossRef]

14. Wang, J.-X.; Li, X.-H.; Wang, Z.-X.; Guo, H.-J.; Zhang, Y.-H.; Xiong, X.-H.; He, Z.-J. Synthesis and characterization of $\mathrm{LiVPO}_{4} \mathrm{~F} / \mathrm{C}$ using precursor obtained through a soft chemical route with mechanical activation assist. Electrochim. Acta 2013, 91, 75-81. [CrossRef]

15. Wang, J.; Liu, Z.; Yan, G.; Li, H.; Peng, W.; Li, X.; Song, L.; Shih, K. Improving the electrochemical performance of lithium vanadium fluorophosphate cathode material: Focus on interfacial stability. J. Power Sources 2016, 329, 553-557. [CrossRef]

16. Hu, G.; Gan, Z.; Cao, Y.; Du, K.; Du, Y.; Peng, Z. A three-dimensional LiVPO 4 F@C/MWCNTs/rGO composite with enhanced performance for high rate Li-ion batteries. Electrochim. Acta 2018, 292, 502-510. [CrossRef]

17. Li, P.; Ma, R.; Lin, X.; Shao, L.; Wu, K.; Shui, M.; Long, N.; Shu, J. Impact of $\mathrm{H}_{2} \mathrm{O}$ exposure on the structure and electrochemical performance of $\mathrm{LiVPO}_{4} \mathrm{~F}$ cathode material. J. Alloys Compd. 2015, 637, 20-29. [CrossRef]

18. Ma, R.; Shu, J.; Shao, L.; Lin, X.; Wu, K.; Shui, M.; Li, P.; Long, N.; Ren, Y. Determination of lithium ion diffusion behaviors in tavorite $\mathrm{LiVPO}_{4} \mathrm{~F}$ by galvanostatic intermittent titration technique. Ceram. Int. 2014, 40, 15113-15119. [CrossRef]

19. Liu, Z.; Fan, Y.; Peng, W.; Wang, Z.; Guo, H.; Li, X.; Wang, J. Mechanical activation assisted soft chemical synthesis of Na-doped lithium vanadium fluorophosphates with improved lithium storage properties. Ceram. Int. 2015, 41, 4267-4271. [CrossRef]

20. Liu, Z.; Peng, W.; Fan, Y.; Li, X.; Wang, Z.; Guo, H.; Wang, J. One-step facile synthesis of graphene-decorated $\mathrm{LiVPO}_{4} \mathrm{~F} / \mathrm{C}$ nanocomposite as cathode for high-performance lithium ion battery. Ceram. Int. 2015, 41, 9188-9192. [CrossRef]

21. Ellis, B.L.; Ramesh, T.N.; Rowanweetaluktuk, W.N.; Ryan, D.H.; Nazar, L.F. Solvothermal synthesis of electroactive lithium iron tavorites and structure of $\mathrm{Li}_{2} \mathrm{FePO}_{4} \mathrm{~F}$. J. Mater. Chem. 2012, 22, 4759-4766. [CrossRef]

22. Recham, N.; Chotard, J.N.; Jumas, J.C.; Laffont, L.; Armand, M.; Tarascon, J.M. Ionothermal synthesis of Li-based fluorophosphates electrodes. Chem. Mater. 2010, 22, 1142-1148. [CrossRef] 
23. Ramesh, T.N.; Lee, K.T.; Ellis, B.L.; Nazar, L.F. Tavorite lithium iron fluorophosphate cathode materials: Phase transition and electrochemistry of $\mathrm{LiFePO}_{4} \mathrm{~F}_{-} \mathrm{Li}_{2} \mathrm{FePO}_{4} \mathrm{~F}$. Electrochem. Solid-State Lett. 2010, 13, A43-A47. [CrossRef]

24. Lee, E.; Persson, K.A. Solid-solution Li intercalation as a function of cation order/disorder in the high-voltage $\mathrm{Li}_{x} \mathrm{Ni}_{0.5} \mathrm{Mn}_{1.5} \mathrm{O}_{4}$ Spinel. Chem. Mater. 2013, 25, 2885-2889. [CrossRef]

25. Huang, Z.-D.; Orikasa, Y.; Masese, T.; Yamamoto, K.; Mori, T.; Minato, T.; Uchimoto, Y. A novel cationic-ordering fluoro-polyanionic cathode $\mathrm{LiV}_{0.5} \mathrm{Fe}_{0.5} \mathrm{PO}_{4} \mathrm{~F}$ and its single phase $\mathrm{Li}^{+}$insertion/extraction behaviour. RSC Adv. 2013, 3, 22935-22939. [CrossRef]

26. Fan, S.-H.; Shao, G.-Q.; Zhu, C.; Ma, F.-F.; Mao, J.-W.; Zhang, A.-L.; Xie, G.-Z.; Yan, J.-L.; Zhang, Y. Crystal structure and electrochemical properties of $\mathrm{LiFe}_{1-x} \mathrm{~V}_{x} \mathrm{PO}_{4} \mathrm{~F}_{1-\delta} \mathrm{O}_{\delta}$ cathode materials for lithium-ion batteries. Electrochim. Acta 2018, 280, 248-257. [CrossRef]

27. Bamine, T.; Boivin, E.; Boucher, F.; Messinger, R.J.; Salager, E.; Deschamps, M.; Masquelier, C.; Croguennec, L.; Ménétrier, M.; Carlier, D. Understanding local defects in Li-ion battery electrodes through combined DFT/NMR studies: Application to $\mathrm{LiVPO}_{4}$ F. J. Phys. Chem. C 2017, 121, 3219-3227. [CrossRef]

28. Kim, M.; Lee, S.; Kang, B. High energy density polyanion electrode material: $\mathrm{LiVPO}_{4} \mathrm{O}_{1-x} \mathrm{~F}_{x}(x \approx 0.25)$ with tavorite structure. Chem. Mater. 2017, 29, 4690-4699. [CrossRef]

29. Boivin, E.; Chotard, J.N.; Ménétrier, M.; Bourgeois, L.; Bamine, T.; Carlier, D.; Fauth, F.; Masquelier, C.; Croguennec, L. Oxidation under air of tavorite $\mathrm{LiVPO}_{4} \mathrm{~F}$ : Influence of vanadyl-type defects on its electrochemical properties. J. Phys. Chem. C 2016, 120, 26187-26198. [CrossRef]

30. Onoda, M.; Ishibashi, T. Phase transition and spin dynamics of the $\mathrm{LiVPO}_{4} \mathrm{~F}$ insertion electrode with the $S=1$ linear chain and the development of F-O mixed system. J. Phys. Soc. Jpn. 2015, 84, 044802. [CrossRef]

31. Ma, R.; Shao, L.; Wu, K.; Shui, M.; Wang, D.; Long, N.; Ren, Y.; Shu, J. Effects of oxidation on structure and performance of $\mathrm{LiVPO}_{4} \mathrm{~F}$ as cathode material for lithium-ion batteries. J. Power Sources 2014, 248, 874-885. [CrossRef]

32. Channu, V.S.R.; Thanedar, $\mathrm{S} . \mathrm{LiV}_{x} \mathrm{Fe}_{y} \mathrm{PO}_{4} \mathrm{~F}$ nanostructure cathodes for lithium ion batteries. In Proceedings of the 230th ECS Meeting, Honolulu, HI, USA, 2-7 October 2016; Abstract MA2016-02, 402. The Electrochemical Society: Pennington, NJ, USA, 2016.

33. Li, B. Preparation and Electrochemical Properties of $\mathrm{LiVPO}_{4} \mathrm{~F}$ Cathode Material for Li-ion Batteries. Master's Thesis, Wuhan University of Technology, Wuhan, China, 2012.

34. Ahrens, L.H. The use of ionization potentials Part 1. Ionic radii of the elements. Geochim. Cosmochim. Acta 1952, 2, 155-169. [CrossRef]

35. Shannon, R.D. Revised effective ionic radii and systematic studies of interatomic distances in halides and chaleogenides. Acta Cryst. 1976, A32, 751-767. [CrossRef]

36. Ellis, B.L.; Ramesh, T.N.; Davis, L.J.M.; Goward, G.R.; Nazar, L.F. Structure and electrochemistry of two-electron redox couples in lithium metal fluorophosphates based on the tavorite structure. Chem. Mater. 2011, 23, 5138-5148. [CrossRef]

37. Yang, Y.; Fang, H.; Zheng, J.; Li, L.; Li, G.; Yan, G. Towards the understanding of poor electrochemical activity of triclinic $\mathrm{LiVOPO}_{4}$ : Experimental characterization and theoretical investigations. Solid State Sci. 2008, 10, 1292-1298. [CrossRef]

38. Lavrov, A.V.; Nikolaev, V.P.; Sadikov, G.G.; Poraikoshits, M.A. Synthesis and crystal structure of mixed lithium vanadyl orthophosphate. Doklady Akademii Nauk SSSR 1982, 266, 343-346.

39. Castro, L.; Dedryvère, R.; El Khalifi, M.; Lippens, P.E.; Bréger, J.; Tessier, C.; Gonbeau, D. The spin-polarized electronic structure of $\mathrm{LiFePO}_{4}$ and $\mathrm{FePO}_{4}$ evidenced by in-lab XPS. J. Phys. Chem. C 2010, 114, 17995-18000. [CrossRef]

40. Yamashita, T.; Hayes, P. Analysis of XPS spectra of $\mathrm{Fe}^{2+}$ and $\mathrm{Fe}^{3+}$ ions in oxide materials. Appl. Surf. Sci. 2008, 254, 2441-2449. [CrossRef]

41. Grosvenor, A.P.; Kobe, B.A.; Biesinger, M.C.; McIntyre, N.S. Investigation of multiplet splitting of Fe 2p XPS spectra and bonding in iron compounds. Surf. Interface Anal. 2004, 36, 1564-1574. [CrossRef]

42. Dedryvère, R.; Maccario, M.; Croguennec, L.; Le Cras, F.; Delmas, C.; Gonbeau, D. X-ray photoelectron spectroscopy investigations of carbon-coated $\mathrm{Li}_{x} \mathrm{FePO}_{4}$ materials. Chem. Mater. 2008, 20, 7164-7170. [CrossRef] 
43. Biesinger, M.C.; Lau, L.W.M.; Gerson, A.R.; Smart, R.S.C. Resolving surface chemical states in XPS analysis of first row transition metals, oxides and hydroxides: Sc, Ti, V., Cu and Zn. Appl. Surf. Sci. 2010, 257, 887-898. [CrossRef]

44. Zhang, B.; Han, Y.-D.; Zheng, J.-C.; Shen, C.; Ming, L.; Zhang, J.-F. A novel lithium vanadium fluorophosphate nanosheet with uniform carbon coating as a cathode material for lithium-ion batteries. J. Power Sources 2014, 264, 123-127. [CrossRef]

45. Zheng, J.-C.; Zhang, B.; Yang, Z.-H. Novel synthesis of $\mathrm{LiVPO}_{4} \mathrm{~F}$ cathode material by chemical lithiation and postannealing. J. Power Sources 2012, 202, 380-383. [CrossRef]

46. Reddy, M.V.; Rao, G.V.S.; Chowdari, B.V.R. Long-term cycling studies on 4 V-cathode, lithium vanadium fluorophosphate. J. Power Sources 2010, 195, 5768-5774. [CrossRef]

47. Barker, J.; Gover, R.K.B.; Burns, P.; Bryan, A.; Saidi, M.Y.; Swoyer, J.L. Structural and electrochemical properties of lithium vanadium fluorophosphate, $\mathrm{LiVPO}_{4}$ F. J. Power Sources 2005, 146, 516-520. [CrossRef]

48. Barker, J.; Saidi, M.Y.; Swoyer, J.L. A comparative investigation of the Li insertion properties of the novel fluorophosphate phases, $\mathrm{NaVPO}_{4} \mathrm{~F}$ and $\mathrm{LiVPO}_{4} \mathrm{~F}$. J. Electrochem. Soc. 2004, 151, A1670-A1677. [CrossRef]

49. Yang, C.-Y.; Ji, X.; Fan, X.-L.; Gao, T.; Suo, L.-M.; Wang, F.; Sun, W.; Chen, J.; Chen, L.; Han, F.-D.; et al. Flexible aqueous Li-ion battery with high energy and power densities. Adv. Mater. 2017, 29, 1701972. [CrossRef] [PubMed]

50. Wu, B.; Yang, X.; Jiang, X.; Zhang, Y.; Wang, X. Synchronous tailoring surface structure and chemical composition of Li-rich-layered oxide for high-energy lithium-ion batteries. Adv. Funct. Mater. 2018, 28, 1803392. [CrossRef]

51. Ellis, B.L.; Nazar, L.F. Anion-induced solid solution electrochemical behavior in iron tavorite phosphates. Chem. Mater. 2012, 24, 966-968. [CrossRef]

52. Weppner, W.; Huggins, R.A. Electrochemical investigation of the chemical diffusion, partial ionic conductivities, and other kinetic parameters in $\mathrm{Li}_{3} \mathrm{Sb}$ and $\mathrm{Li}_{3} \mathrm{Bi}$. J. Solid State Chem. 1977, 22, $297-308$. [CrossRef]

53. Xiao, P.-F.; Lai, M.-O.; Lu, L. Transport and electrochemical properties of high potential tavorite $\mathrm{LiVPO}_{4} \mathrm{~F}$. Solid State Ion. 2013, 242, 10-19. [CrossRef]

54. Prosini, P.P.; Lisi, M.; Zane, D.; Pasquali, M. Determination of the chemical diffusion coefficient of lithium in $\mathrm{LiFePO}_{4}$. Solid State Ion. 2002, 148, 45-51. [CrossRef]

55. Tang, K.; Yu, X.; Sun, J.; Li, H.; Huang, X. Kinetic analysis on $\mathrm{LiFePO}_{4}$ thin films by CV, GITT, and EIS. Electrochim. Acta 2011, 56, 4869-4875. [CrossRef]

56. Muraliganth, T.; Manthiram, A. Understanding the shifts in the redox potentials of olivine $\mathrm{Li}_{1-y} \mathrm{M}_{y} \mathrm{PO}_{4}$ ( $M=\mathrm{Fe}, \mathrm{Mn}, \mathrm{Co}$, and Mg) solid solution cathodes. J. Phys. Chem. C 2010, 114, 15530-15540. [CrossRef]

57. Kobayashi, G.; Yamada, A.; Nishimura, S.I.; Kanno, R.; Kobayashi, Y.; Seki, S.; Ohno, Y.; Miyashiro, H. Shift of redox potential and kinetics in $\mathrm{Li}_{x}\left(\mathrm{Mn}_{y} \mathrm{Fe}_{1-y}\right) \mathrm{PO}_{4}$. J. Power Sources 2009, 189, 397-401. [CrossRef]

58. Yamada, A.; Takei, Y.; Koizumi, H.; Sonoyama, N.; Kanno, R.; Itoh, K.; Yonemura, M.; Kamiyama, T. Electrochemical, magnetic, and structural investigation of the $\mathrm{Li}_{x}\left(\mathrm{Mn}_{y} \mathrm{Fe}_{1-y}\right) \mathrm{PO}_{4}$ olivine phases. Chem. Mater. 2006, 18, 804-813. [CrossRef]

59. Melot, B.C.; Tarascon, J.M. Design and preparation of materials for advanced electrochemical storage. Acc. Chem. Res. 2013, 46, 1226-1238. [CrossRef] [PubMed]

60. Girish, H.N.; Shao, G.-Q. Advances in high-capacity $\mathrm{Li}_{2} \mathrm{MSiO}_{4}(\mathrm{M}=\mathrm{Mn}, \mathrm{Fe}, \mathrm{Co}, \mathrm{Ni}, \ldots)$ cathode materials for lithium-ion batteries. RSC Adv. 2015, 5, 98666-98686. [CrossRef]

61. Larson, A.C.; Von Dreele, R.B.; General Structure Analysis System (GSAS). Report LAUR 86-748; Los Alamos National Laboratory: Los Alamos, NM, USA, 2004; pp. 86-748.

Sample Availability: Samples of the compounds $\mathrm{VPO}_{4}, \mathrm{LiFe}_{1-x} \mathrm{~V}_{x} \mathrm{PO}_{4} \mathrm{~F}(x=0,0.3,1)$ are available from the authors. 